\title{
Eruption mechanisms and short duration of large rhyolitic lava flows of Yellowstone
}

\author{
Matthew W. Loewen ${ }^{1}$, Ilya N. Bindeman ${ }^{1}$, and Oleg. M. Melnik ${ }^{1,2}$ \\ ${ }^{1}$ Department of Geological Sciences, University of Oregon, Eugene, OR 97403-1272 \\ ${ }^{2}$ Institute of Mechanics, Moscow State University, Moscow 119192, Russia
}

Corresponding Author: Matthew W. Loewen, loewenm@uoregon.edu 


\begin{abstract}
Large-volume effusive rhyolite lava flows are a common but poorly understood occurrence from silicic volcanic centers. We integrate characterization of lava flow topographic morphology and petrographic textures and zoning of crystals with physical models of viscous fluid flow in order to interpret the eruption durations and discharge rates for the most recent effusive volcanic eruptions from Yellowstone. These large-volume $\left(10-70 \mathrm{~km}^{3}\right)$ crystal-poor rhyolite lavas erupted within the Yellowstone caldera as 100-200 m thick flows and have a cumulative erupted volume of $650 \mathrm{~km}^{3}$ that is similar to less frequent caldera-forming events, but occur as individual eruptions spread over $\sim 100 \mathrm{ka}$. Most of this work is focused on the axisymmetric $124 \mathrm{ka}, \sim 50 \mathrm{~km}^{3}$ Summit Lake flow. We examined crystallinity, major and trace element concentrations, oxygen and hydrogen isotopic values, and quartz morphology and zoning in samples from the center to margin of this flow. Water contents down to $0.1 \mathrm{wt} . \%$ and $\delta \mathrm{D}$ values of $-110 \%$ are low and require closed-system degassing until near-surface lithostatic pressure, while major elements are consistent with water-undersaturated pre-eruptive storage and crystallization at $\sim 4-8 \mathrm{~km}$ depth. We found some evidence for subtle $\mathrm{km}$-scale zoning within the lavas but describe significant microscopic scale compositional diversity including sharp boundaries between high-Ti cores and $\sim 200 \mu \mathrm{m}$ thick rims on quartz phenocrysts. Embayed quartz external morphology and rim growth may be the result of undercooling during coalescence of a magma bodies during shallow transport between dikes and sills. Modeling the emplacement of the lava flow as a simple viscous fluid suggests that emplacement of rhyolite lava at $\sim 800^{\circ} \mathrm{C}$ occurred over $\sim 2$ to 5 years with high discharge rates $>100 \mathrm{~m}^{3} / \mathrm{s}$. Such high magma discharge rates are accommodated through $\sim 6 \mathrm{~km}$-long fissures that allow for slower magma ascent velocities of $<1 \mathrm{~cm} / \mathrm{s}$ required for eruptions to remain dominantly effusive. Lower
\end{abstract}


temperatures will result in $>10$ year flow durations and significant cooling of the flow front that should result in a more complex compound flow morphology than observed. Higher temperatures require unrealistically wide $(>50 \mathrm{~m})$ dike widths to accommodate large discharge rates. Petrographic and isotopic evidence from crystals suggests recharge and merger of individual magma batches occurs on a similar timescale to the eruption duration and may directly cause overpressure and emplacement of these rhyolite lava flows from a shallow, ephemeral magma chamber. Large-volume rhyolitic lavas are able to erupt effusively through elongate fissures that utilize preexisting zones of crustal weaknesses such as ring fractures. Less-common explosive eruptions at Yellowstone may result when ascending magmas are forced through narrower conduits or when recharge rates are especially high. The results of this study provide a unique "top-down" constraint on effusive eruption rates, make new interpretations of common petrographic textures, and presents a comprehensive model for eruption control.

\section{Keywords}

Yellowstone; rhyolite lavas; quartz morphology; viscous flow models; lava flow cooling

\section{Introduction}

Large centers of rhyolitic volcanism receive a great deal of attention for their calderaforming "supereruptions." These largest eruptions may be responsible for major climate perturbations in the Earth's history (e.g., Self and Blake, 2008). Their underlying magma systems play a critical role in development and evolution of the Earth's crust (e.g., Hildreth and Moorbath, 1988; Huppert and Sparks, 1988). Many recent studies have focused on the eruption mechanisms and triggers of these largest caldera-forming tuffs (e.g., Gregg et al., 2015), while 
less attention has been devoted to the eruption mechanisms of more common but less publicized effusive rhyolite flows from these volcanic centers.

While direct observations exist for small-volume rhyolite eruptions and many silicic domes, primarily in arc volcanic settings (e.g., Castro and Dingwell, 2009; Pallister et al., 2013; Tuffen et al., 2013), eruption of large-volume rhyolitic lavas have never been observed. Therefore, interpretation of the eruption processes for large-volume rhyolite lava flows is constrained only by the observed physical features of prehistoric flows (de Silva et al., 1994; Manley, 1996; Fink and Griffiths, 1998). In recent years significant progress of lava flow simulations was achieved starting from analytical solutions (Huppert, 1982) to fully 3D nonisothermal lava flow models (Hidaka et al., 2005). In the case of prehistoric lava flows with parameters that are hard to constrain, including discharge rate, vent shape, and emplacement temperature, an obvious solution is to use a simple modeling strategy to gain first order constraints on eruption dynamics.

The Yellowstone Plateau is one of the largest and most well-recognized centers of rhyolitic volcanism in the world, most noted for its massive caldera-forming "supereruptions" such as the most recent $630 \mathrm{ka}$ Lava Creek Tuff. Since this eruption the caldera has been filled with numerous effusive lava flows, including the products of the most recent Central Plateau Member (CPM) period of volcanism from 180-70 ka. These flows have volumes up to $70 \mathrm{~km}^{3}$, with 16 individual flows of over $2 \mathrm{~km}^{3}$, and only 2 mapped occurrences of significant tuff deposits (Christiansen et al., 2007; Fig. 1A). The cumulative $650 \mathrm{~km}^{3}$ volume of these flows is comparable to that of a large caldera-forming supereruption, and thus the CPM has sometimes been considered a "fourth" caldera cycle with a series of voluminous flows occurring over a 100 ka period instead of as a single catastrophic caldera-forming eruption (Christiansen and Blank, 
1972; Hildreth et al., 1984). The CPM rhyolites provide an ideal setting to test models of rhyolite lava eruption mechanisms with some of these largest and most exceptional examples of rhyolite flows on earth.

In this contribution we are interested in understanding the eruption mechanics of these large-volume rhyolite lava flows. We constrain eruption timescales and temperature by integrating observations from large, km-scale lava flow topographic morphology and small $\mu \mathrm{m}-$ scale quartz crystal growth textures with analytical solutions to gravity-driven viscous fluid flow. These models provide intersecting constraints on the required rates of eruption, magma ascent, and conduit size of large-volume rhyolite lava flows at Yellowstone and thus can provide insight into the volcanic hazards and mechanics of the underlying magma system from this and other rhyolitic volcanic centers.

\section{The Summit Lake rhyolite flow}

We have chosen to focus this work on the $\sim 400 \mathrm{~km}^{2}$ interglacial Summit Lake rhyolite flow erupted at $124 \mathrm{ka}$ (Christiansen et al., 2007; Fig. 1B). The flow is relatively symmetrical compared to synglacial CPM lavas that were likely constrained by ice during eruption and have more complex compound flow morphologies (Lescinsky and Fink, 2000; Christiansen, 2001). The majority of the Summit Lake flow margin is exposed except in the northwest where it is partially overlain by the $114 \mathrm{ka}$ West Yellowstone flow (Fig. 1A). These characteristics make it especially well-suited for approximation using physical models of viscous fluid flow.

Despite its $100 \mathrm{ka}$ age and subsequent glaciation, the Summit Lake flow is remarkably well-preserved. River incision forms sharp v-shaped valleys typically no more than 10-20 m deep, with only two instances of river erosion significantly deeper than $30 \mathrm{~m}$ : in a drainage on 
the southern tip of the flow and along the West Fork Iron Spring Creek in the northeast (Fig. 1C). Primary flow features such as ogives are mapped on this and other Yellowstone CPM rhyolites by Christiansen (2001) and the surface is vitrophyric obsidian, characteristic of an upper quenched flow surface. These observations suggest that the original flow morphology is wellpreserved and erosion has been minimal. No remnants of any pyroclastic components have been mapped or reported in this or other CPM lava flows. Initial glaciation of the Summit Lake flow occurred by $114 \mathrm{ka}$ when the synglacial West Yellowstone flow was emplaced (see Fig. 1 for units; Pierce and Obradovich, 1976; Christiansen, 2001). Glacial cover may have been more or less continuous from this point until the 14 ka cessation of the Pinedale glaciation during the last glacial maximum (Licciardi and Pierce, 2008). Geomorphic preservation of this flow may be due to, rather than in spite of, this extensive glacial history; location along the continental divide and within the broad Yellowstone Plateau resulted in low basal ice velocities and subsequently minor glacial erosion.

\section{Materials and methods}

In order to characterize the entire chronology of the Summit Lake flow and gain insights into the origin and eruption of its magma, we have collected 20 samples from the topographic high and inferred vent location (08YS-01) to the northeast margin of the flow (08YS-20; see Fig. 1B and supplementary file 1 for exact locations). These samples represent the final (08YS-01) and earliest (08YS-20) erupted products from, as we demonstrate later and in agreement with Christiansen (2001), a simple rather than compound flow. Whole rock major and trace elements were characterized by X-Ray Fluorescence (XRF) at Pomona College. Matrix glass trace element concentrations determined by Laser Ablation-ICP-MS at Oregon State University and 
oxygen isotope values were determined by Laser Fluorination IRMS at the University of Oregon, and these results are also reported in Loewen and Bindeman (2015). Water concentrations and hydrogen isotope values for glass were determined by a Thermal Conversion Elemental Analyzer (TC/EA) following the approach of Loewen and Bindeman (2015). Quartz Ti concentrations were determined on a Cameca SX-100 Electron Microprobe (EMPA) at the University of Oregon, and Cathode Luminescence (CL) images obtained on another SX-100 EMPA at Oregon State University.

\section{Summit Lake lava flow composition and mineral textures}

The Summit Lake lava is a low-crystallinity (3-6\%) high-silica rhyolite (76 wt.\% $\mathrm{SiO}_{2}$; Table 1) typical of other Yellowstone CPM lavas (Fig. 2A). Quartz and sanidine are the dominant crystal phases with minor Fe-Ti oxides, clinopyroxene, and accessory zircon and chevkinite. Normative major element compositions plot between the 100 and $200 \mathrm{MPa}$ quartzfeldspar cotectic on Fig. 2A (Blundy and Cashman, 2001), corresponding to shallow depths of 4 $\mathrm{km}$ and are consistent with cotectic minima for water-undersaturated rhyolites (Hotlz et al., 1992). Quartz-sanidine mineralogy and overall low crystallinity are consistent with RhyoliteMELTs (Gualda et al., 2012a) for $\sim 800-850^{\circ} \mathrm{C}$ with 2-3 wt.\% initial water (Fig. 2B).

Oxygen isotope values are low (median $\delta^{18} \mathrm{O}=4.6 \%$ ) and similar to other CPM rhyolites (Loewen and Bindeman, 2015), requiring magma generation from remelting of a shallow protolith that experienced hydrothermal alteration (e.g., Bindeman and Valley, 2001). Crystallinity is slightly higher and $\delta^{18} \mathrm{O}$ slightly lower in the earliest erupted samples collected closest to the flow margin (Fig. 3). Other major and trace elements follow these small changes in crystallinity (e.g. $\mathrm{Nb}, \mathrm{Ba}$ ) but overall show little to no systematic changes from early to late 
erupted samples. Whole rock concentrations of most elements are higher than matrix glass concentrations reflecting compatibility with sanidine and accessory minerals, similar to the pattern observed in other CPM rhyolites (Loewen and Bindeman, 2015). Glass next to zircon crystals in low $\mathrm{Zr}$ glass exhibit greater $\mathrm{Zr}$ concentrations indicative of preeruptive heating episode of $\sim 15^{\circ} \mathrm{C}$ (Loewen and Bindeman, 2015; Bindeman and Melnik, 2016).

Water concentrations and $\delta \mathrm{D}$ values are uniformly low across the entire surface of the Summit Lake and other CPM rhyolites (Fig. 4). All Summit Lake samples have $\leq 0.15$ wt.\% water consistent with water solubility in a rhyolite melt at $<10 \mathrm{~m}$ lithostatic pressure (Newman and Lowenstern, 2002). These values are broadly similar to water concentrations and $\delta \mathrm{D}$ values for other CPM rhyolites (Loewen and Bindeman, 2015). Higher water contents are observed in other flows at Yellowstone, however, these higher values are accompanied by $\delta \mathrm{D}$ values <$130 \%$ that can only result from secondary hydration with low $\delta \mathrm{D}$ meteoric water (Fig. 4;

Bindeman and Lowenstern, 2016). The typical low water glass samples are consistent with twostage degassing from primary magmatic water of $\delta \mathrm{D}=-50 \%$ and $3 \mathrm{wt} . \%$ total water with closed-system degassing to near-surface lithostatic pressures followed by open-system degassing (e.g., Newman et al. 1988; Taylor, 1991). These isotopic values and water contents require that degassing occurred very near the vent surface or via an open fracture network connected to the surface. This could be accomplished through fragmentation and degassing at the vent as observed in the 2011-2012 eruption of Cordón Caulle (Schipper et al., 2013; Castro et al., 2014). This near-vent fragmentation would also effectively expose the entire lava pile on all sides to near-surface conditions resulting in the low water contents observed in all CPM lavas. Despite this evidence, it remains possible that higher water contents exist deep within the flow interior under meters to tens meters overpressure. Our sampling and water and $\delta \mathrm{D}$ determinations of 30 
samples from Summit Lake and other Yellowstone lava flows — some of which likely sampled flow interiors exposed by glacial or other erosion — did not reveal magmatic water concentrations in matrix glass higher than $0.22 \mathrm{wt} . \%$.

Quartz phenocrysts imaged from across the Summit Lake flow display zoning patterns of dark CL and low-Ti rims surrounding bright CL, higher-Ti cores (Fig. 5, 6). The cores are typically rounded, and their internal oscillatory zoning is often truncated by the rim overgrowth (e.g., Fig. 5G). Similar quartz zoning patterns have been observed in most other CPM flows, including the adjacent Buffalo Lake, West Yellowstone, and Pitchstone Plateau flows (Vazquez et al., 2009; Girard and Stix, 2010). Girard and Stix (2010) also noted that quartz phenocrysts without the strong zoning have identical Ti concentrations as the rims of zoned crystals from the same flow. Quartz cores with higher and lower-Ti concentrations occur side by side suggesting magma batches merge with slightly different temperature and/or Ti concentrations and activities. We do not observe any changes of quartz rim or core Ti concentrations from early to late erupted samples (Fig. 3). Quartz phenocrysts display complex external morphologies ranging from anhedral crystals (Fig. 5F, G) to euhedral hexagonal forms with (Fig. 5C, D, E, I, J, M) and without (Fig. 5A, B, H, K, L) embayments. Quartz phenocrysts in the earliest erupted sample are often fragmented (Fig. 5N, O, P).

\section{Origin of quartz morphology and low-Ti rims}

In this work we investigate the possibility that the embayments and low-Ti rims in quartz are a result of rapid growth occurring within a few years of eruption. Embayments in crystals can be a result of either dissolution (reentrants), or as a result of rapid crystal growth where crystal edges and corners grow preferentially to crystal faces resulting in a hopper or skeletal 
morphology (Roedder, 1979). Embayed quartz phenocrysts, as observed in Summit Lake and other CPM rhyolites, are commonly assumed to be reentrants resulting from partial dissolution (e.g., Girard and Stix, 2010). We document, however, that the quartz embayments observed in the Summit Lake and other CPM lavas are more consistent with long-standing observational (Lemmlein, 1930; Anderson, 1991) and experimental (Swanson and Fenn, 1986, Cabane et al., 2001) descriptions of quartz habits that are a result of primary late-stage hopper-style growth. Many of the quartz textural features illustrated in Fig. 5 can only be explained by crystal growth. Complete to partial annealing of hopper growth habits are clearly shown in Fig. 5D, where internal oscillatory zoning traces hopper growth patterns. The growth bands eventually enclose some embayments resulting in fully entrapped melt inclusions or embayments connected to external melt only by narrow necks. These "hourglass-type" melt inclusions (see also Fig. 5C, E, and M), as described by Anderson (1991), are difficult to envision forming by crystal dissolution and therefore are a diagnostic feature of crystal growth. In all samples examined by us and previous studies (Vazquez et al., 2009; Girard and Stix, 2010), we have found only one case where an embayment is not confined entirely to the crystal rim (Fig. 5C). It is possible that in this one crystal, hopper overgrowth (forming the narrow neck) occurs coincidently as an extension of an earlier reentrant-type embayment in the core. In addition to the embayments, we observe euhedral quartz phenocryst external forms with strongly faceted faces and hexagonal beta-quartz symmetry (Fig. 5A, B, C, D, E, H, I, J, K, L, M). These hexagonal forms and even the less common rounded quartz phenocrysts (Fig. 5F, G) are likely to represent equilibrium quartz growth textures, not dissolution (e.g., Cabane et al., 2001).

Unlike embayments that are primarily confined to low-Ti rims, there is evidence for complex history of high-Ti crystal cores including convincing evidence for an earlier history 
crystal dissolution. This earlier dissolution event is illustrated in Fig. 5G, where the bright-CL core has oscillatory zoning that is truncated by rim overgrowth. The core also has a reentranttype embayment with a small melt inclusion. Other bright CL-cores, however, provide evidence for earlier periods of skeletal growth, notably Fig. 5I and L, suggesting a potentially diverse origin for quartz phenocrysts. Previous studies have described declining quartz rim and core Ti concentrations through time with core compositions strikingly similar to rim compositions from previous CPM eruptions (Vazquez et al., 2009; Girard and Stix, 2010; see electronic supplement 2). These observations support that the high-Ti cores must represent an antecrystic history of melt composition.

Perhaps more important is the preservation of a sharp boundary between high-Ti cores and low-Ti rims that provides some constraints on the timescale of rim growth. EMPA profiles were measured across core-rim boundaries on two quartz phenocrysts, one from an early and one from a late erupted sample (Fig. 6). The transition from $\sim 150 \mathrm{ppm}$ core to $\sim 100 \mathrm{ppm}$ rim Ti concentrations occurs over less than the 10-20 $\mu \mathrm{m}$ spacing of EMPA analyses. We use CLgreyscale calibrated to Ti concentrations determined by EMPA, following Wark et al. (2007), in order to characterize this transition at higher spatial resolution. In both transects, the transition occurs over a 5-7 $\mu \mathrm{m}$ distance, equivalent to $<10$ pixels in the original CL image. At this short distance, we cannot be certain that some of the diffusion profile could be due to the resolution limits of our images and detector. As a result, we consider that models fit to this compositional profile provide only an estimate of maximum timescale; the actual compositional profile could be an even sharper step function than what we model.

We fit diffusion curves following the approach of Gualda et al. (2012b), using temperature dependent diffusion coefficients from Cherniak et al. (2007). The resulting timescale 
for the best-fit diffusion curves shown in Fig. 6 are highly dependent on assumed temperature. The sharpest Ti profile from 08YS-20 could be preserved for only 1 year at $850^{\circ} \mathrm{C}, 3$ years at $800^{\circ} \mathrm{C}$, and 15 years at $750^{\circ} \mathrm{C}$ (Fig. 6B; Table 1 ). The later erupted 08 YS- 02 has a slightly longer profile modeled with 5-6x longer durations (Fig. 6A), although this more relaxed profile could be due to an oblique intersection of zoning that will also result in longer time estimates.

The formation of hopper growth patterns and low-Ti rims must occur in response to an abrupt undercooling event within a few years to decades of eruption and quenching to preserve sharp Ti-zonation (Fig. 6). Based on the transitional hopper to equant morphology that we observe here (Fig. 5) and experimental observations of Swanson and Fenn (1986), this undercooling must have been somewhat less than $50^{\circ} \mathrm{C}$ with larger degrees of undercooling resulting in more dendritic growth forms (e.g., spherulites at the surface; Befus et al., 2015a). Decompression during magma ascent is an easy mechanism to produced large degrees of undercooling, and is associated with microlite development in Summit Lake and other CPM rhyolites (Befus et al., 2015b). However, decompression will also shift the quartz-feldspar cotectic (Fig. 2A), resulting in the observed crystallization of feldspar microlites with no quartz microlite or rim growth (Blundy and Cashman, 2001).

Instead, we propose that quartz growth occurs in response to magma mixing within years of and/or during eruption. Yellowstone-Snake River Plain rhyolites are noted for exceptionally high $\left(850-950^{\circ} \mathrm{C}\right)$ and bimodal temperature distributions (Loewen and Bindeman, 2016). The high Ti antecrystic cores can be incorporated into a magma in a hot melt zone, as described in Loewen and Bindeman (2015). Rapid growth textures forming typical $~ 200 \mu \mathrm{m}$ low-Ti rims occur during undercooling as the magmas are abruptly brought into a colder, pre-eruptive magma chamber via inter-connected dikes and sills within hydrothermally-cooled shallow country rocks. 
Quartz rims will require $\sim 6$ years to form using quartz growth rates proposed by other studies

(Pamuku et al., 2015), closely matching the diffusive time scales from Ti zoning and the eruption durations that we model below.

\section{Lava flow morphology and topographic profiles}

We here demonstrate that the Summit Lake rhyolite is a prime example of an axisymmetric lava flow propagated over a horizontal surface, and thus is well-suited for application of an analytical solution of simple Newtonian fluid flow to estimate the duration of its emplacement. First, we can demonstrate that the underlying surface of the Summit Lake flow is essentially horizontal. We can estimate the maximum potential underlying slopes by projecting the typical $92 \mathrm{~m}$ thickness at the margin toward the center of the flow, following Christiansen et al. (2007; Fig. 7). The resulting average slopes are $<2^{\circ}$, suggesting emplacement on essentially the flat surface. The low angle creates minimal potential for influence on lava flow velocity from the typical underlying slope (e.g., Lister, 1992).

Further analysis of the Summit Lake flow shape and surrounding topography can provide insight into its likely thickness and volume, and the geometry of the underlying topography. The B-B' section is notably asymmetric with the flow extending $2 \mathrm{~km}$ to the north and over $22 \mathrm{~km}$ to the south of the topographic high and location of the inferred vent. There is no current topographic high to the north that would constrict the lava flow in this direction. Instead, there must be a preexisting topographic high restricting flow to the north and quickly sloping downward towards the Summit Lake vent. In the southern limb of the B-B' section, the older Buffalo Lake and Bechler River flows bound the Summit Lake flow to the east and west. This 
boundary channelized the flow and, along with an apparent break in the underlying slope of $\sim 3.6^{\circ}$, resulted in an elongate lobe.

Compared to the B-B' section, A-A' has a symmetrical topographic profile to $11.3 \mathrm{~km}$ on either side of the inferred vent (Fig. 1B). A circle with this same radius has exactly the same 400 $\mathrm{km}^{2}$ surface area as the mapped Summit Lake flow. The similarity of this surface area, the lack of channelized flow features, and generally even flow margins (Fig. 1), all suggest that the Summit Lake lava flow was a simple rather than compound flow and well-suited for modeling with a symmetrical, gravity-driven viscous flow model over a near-horizontal surface. They symmetry of the A-A' profile also supports making a simplifying assumption that the base elevation was essentially horizontal along this axis of the flow. Therefore, we can estimate a potential maximum flow thickness of $230 \mathrm{~m}$ below the vent.

\section{Vent characteristics}

Our field examination of the center of the Summit Lake flow and examination of topographic surfaces using digital elevation models (Fig. 1,7) suggests that the eruption originated from a NW-SE trending fissure-like vent consisting of a series of craters now filled with lakes or swamps (Fig. 1, electronic supplement 3). We estimate that this vent was likely no longer than $6 \mathrm{~km}$ based on the length of the topographic high along C-C' (Fig. 7). It likely coalesced into one or two isolated vents on the northern end of this fissure towards the end of the eruption, possibly at the crater-like topographic features visible in Fig. 1C (see also electronic supplement 3). Christiansen (2001) identified single-point vent locations at this and other CPM rhyolites, although Christiansen et al. (2007) proposed that at least the Pitchstone Plateau initiated as a more elongate fissure. In agreement with our observations, Befus et al. (2015b) 
used microlite sizes, orientation, and inferred ascent rates to propose that other large CPM rhyolites erupted from 5-10 km long fissures. For our models, we consider both point-source and elongate fissure solutions.

\section{Magma-discharge estimates by a viscous flow model}

Previous analog studies (e.g., Fink and Griffiths, 1998) demonstrated that low crystallinity and axisymmetric lava flows can be modeled with isothermal Newtonian models of viscous fluids (e.g., Huppert et al., 1982). As a lava flow cools, however, the yield strength of a thickening cooled crust will exert primary control on lava flow behavior, requiring application of a viscoelastic model (e.g., Blake 1990; Balmsforth and Craster, 2000), but also resulting in more complex compound flow morphologies (Fink and Griffiths, 1998). As we have demonstrated in our examination of the Summit Lake and surrounding topography, these complicating features are virtually absent and thus this large volume rhyolite flow is an ideal candidate for modeling with a simple gravity-driven viscous fluid model over an essentially horizontal surface following analytical solutions from the Huppert (1982). We first consider a point source (axisymmetric) solution that we later compare to an elongate source (plane-symmetric) solution.

We apply a simple magma-discharge analytical solution from Huppert (1982) relating flow shape and thickness, discharge, and magma ascent rates to the symmetrical A-A' section. Asymptotic analysis of this thin-layer approximation for Stokes equations predicts the shape for a flow generated from a point source with constant discharge:

$$
F(z)=\left(\begin{array}{lll}
1 & z
\end{array}\right)^{1 / 3}\left(\begin{array}{ll}
1 & 0.076 z
\end{array}\right) .
$$

Here $F(z)$ is the dimensionless thickness of the flow and $z=r / r_{n}$ is the dimensionless radius of the flow, where $r_{n}$ is the flow front radii. We apply this equation to the $11.3 \mathrm{~km}$ radius and $230 \mathrm{~m}$ 
flow thickness. The flow shape modeled using eqn. 1 closely matches the observed flow profile along A-A' (Fig. 7). ${ }^{1}$ Assuming a flat underlying surface and symmetric flow with the shape and dimensions described above, we calculate flow volume, $V$, to be $57 \mathrm{~km}^{3}$. This volume is 1.5 times the $37 \mathrm{~km}^{3}$ volume estimated by Christiansen et al. (2007) who assumed a constant $92 \mathrm{~m}$ thickness, which we demonstrated above to be not feasible given the overall flow shape. Nonetheless, the two volume estimates are reasonably similar given the unknowable topography of the underlying surface.

Following Huppert (1982) the relation between discharge rate $Q\left(\mathrm{~m}^{3} / \mathrm{s}\right)$, magma density $\rho$, viscosity $\mu$, acceleration of gravity $g$, time $t$, and the radius of the flow front $r_{n}$, can be written as:

$$
r_{n}=0.715 \frac{g Q^{3}}{3} \div t^{1 / 2} .
$$

Substituting $t=V / Q$, using the symmetrical radius $\left(r_{n}\right)$ and volume $(V)$ approximation determined for the Summit Lake flow, assuming $\rho=2350 \mathrm{~kg} / \mathrm{m}^{3}$ for rhyolite lava ${ }^{2}$ and $g=9.8$ $\mathrm{m} / \mathrm{s}^{2}$, one can obtain the following relationship between the discharge rate and emplacement viscosity, $\mu(\mathrm{Pa} \bullet \mathrm{s})$ of the magma:

$$
Q=\frac{210^{13}}{}
$$

\footnotetext{
${ }^{1}$ Wadge (1981) showed that significant decay in eruption intensity with time is commonly observed based on the analysis of a large number of effusive eruptions. The characteristic decay time depended on the size of a magma chamber, magma compressibility, and wallrock elastic properties. These factors cannot be estimated with desirable accuracy for these prehistoric eruptions. In addition, Huppert (1982) predicts different flow shapes for increasing or decreasing discharge rates, while the Summit Lake flow shape closely matches the profile predicted for constant discharge (Fig. 7). In our study, we propose that batch coalescence caused by contemporaneous refills prior to eruptions creates such constant discharge condition from a shallow reservoir.

${ }^{2}$ Densities for high silica rhyolite may be 2-5\% lower than the value we use here (Saubin et al., 2016), but any change within this range will have an insignificant effect on the results of these calculations.
} 
We estimate melt viscosities with the recently published formulation of Romaine and Whittington (2015) that is specifically designed to estimate high silica rhyolite viscosity at low water concentrations experienced at near surface pressures. Temperature and water concentrations are the critical unconstrained variables in this calculation. We use a water concentration of $0.2 \mathrm{wt} . \%$, slightly higher than our typical measured water concentrations (Fig. 4), reasoning that the bulk lava flow should be an average of these low water surface samples and slightly higher water concentrations that may be possible at depth within the flow. However, based on our measurements of water we consider a lower end of $0.1 \mathrm{wt} . \%$ also to be realistic estimate, should the magmatic degassing be more efficient, and we thus quote solutions for 0.1 wt. $\%$ water in Table 1 . We consider a temperature range between 750 and $850^{\circ} \mathrm{C}$. Lowcrystallinity (3-6\%) and low vesicularity in the Summit Lake and other CPM lavas supports our direct use of melt viscosity.

The resulting viscosities are $10^{9}-10^{11} \mathrm{~Pa} \bullet$ s for surface lavas with temperatures between 750 and $850^{\circ} \mathrm{C}$, and these values overlap the range of other rhyolite lava viscosity estimates (e.g., Farquharson et al., 2015). Overall, we consider that estimates of potential viscosities have an uncertainty of perhaps one order of magnitude (based on different published viscosity models, temperature, water concentration, influence of microlites, etc.) compared to a factor of 1.5 uncertainty in volume estimates. Since temperature is the most unconstrained variable in melt viscosity at the surface, lava temperature is also the largest variable in our discharge estimates. The temperature is most likely between $800-850^{\circ} \mathrm{C}$ based on the crystal-poor, near-liquidus character of lavas and multiple petrologic estimates of CPM temperatures (Bindeman and Valley, 2001; Vazquez et al., 2009; Girard and Stix, 2010; Watts et al., 2012; Loewen and Bindeman 2015), with the exception of Befus and Gardner (2016) who advocate $\sim 750^{\circ} \mathrm{C}$. 
Examples of our modeling results are summarized in Table 1. Using eqn. 3 at a temperature of $850^{\circ} \mathrm{C}$ we estimate a $\sim 6000 \mathrm{~m}^{3} / \mathrm{s}$ average discharge rate with a 4-month lava flow duration. At $800^{\circ} \mathrm{C}$ we estimate a $~ 900 \mathrm{~m}^{3} / \mathrm{s}$ average discharge rate with a 2-year duration. At near-solidus temperatures of $750^{\circ} \mathrm{C}$, the discharge rate would decrease to $120 \mathrm{~m}^{3} / \mathrm{s}$ and duration increases to 16 years. Similar compositions, eruption temperatures, volume, and comparable vent geometries of other CPM lavas should give similar durations. For example, calculations for the 79 ka Pitchstone Plateau flow gives broadly similar eruption-rate estimates (500 to $23,000 \mathrm{~m}^{3} / \mathrm{sec}$ over 1 month to 5 years for 750 to $850^{\circ} \mathrm{C}$ temperatures, see electronic supplement 4). However the younger rhyolites erupted in the vicinity, against or beneath glaciers complicated their morphology (Lescinsky and Fink, 2000; Christiansen 2001; Fig. 1) and the above analysis of pure gravity driven flow may not be strictly applicable.

Eruption of the Summit Lake lava along an elongate fissure presents a challenge to application of a point-source discharge model. Thus, we consider another end-member case: twodimensional plane-symmetric solution for an outflow from an elongate fracture with laterally symmetrical outflow. The solution from Huppert (1982) gives

$$
Q=\frac{5.6 \times 10^{8} L_{f}}{\mu}
$$

where $L_{f}$ is the length of the feeding dike. To match the $57 \mathrm{~km}^{3}$ observed lava flow volume with the volume predicted by the geometry of the equation solution, a $L_{f}=14.8 \mathrm{~km}$ is required. For the temperature of $850^{\circ} \mathrm{C}$ this solution results in a $Q=2000 \mathrm{~m}^{3} / \mathrm{s}$ compared to $6000 \mathrm{~m}^{3} / \mathrm{s}$ estimated from eqn. 3 for a point source, and a total lava flow duration of 10 months (Table 1). This leads to an increase in the duration of the eruption by a factor of 2.5 compared to the case of the point source. Similarly, the elongate (plain-source) source solution at $800^{\circ} \mathrm{C}$ is $400 \mathrm{~m}^{3} / \mathrm{s}$ over 5 years and at $750^{\circ} \mathrm{C}$ is $50 \mathrm{~m}^{3} / \mathrm{s}$ over 40 years. 
The topographic high of the Summit Lake flow that we observe (Fig. 1,7) suggests that fissure length was likely $\sim 6 \mathrm{~km}$ long and did not extent over the entire north-south extent of the flow. Because eqn. 4 only assumes flow perpendicular to the fissure, volumes calculated using $L_{f}$ $=6 \mathrm{~km}$ will be smaller than the minimum $37 \mathrm{~km}^{3}$ estimated by Christiansen (2001). This volume discrepancy demonstrates that for a likely $6 \mathrm{~km}$-length fissure, flow behavior will have both elements of the plane-symmetric solution (eqn. 4) with flow perpendicular to the fissure, and axisymmetric behavior modeled by eqn. 1-3. As a result, discharge rates and associated lava flow durations will be somewhere between these two solutions (Table 1).

Given these approximate discharge rates and flow durations at $850^{\circ} \mathrm{C}$, we can also estimate the maximum rate of flow advance using the point source solution. Assuming constant discharge rates and the geometric relationship of volume and a circular flow propagation, the lavas should initially advance at $\sim 400 \mathrm{~m} /$ day and slow to $50 \mathrm{~m} /$ day. These results demonstrate that even extraordinarily large-volume rhyolite flows may advance relatively slowly and lifethreatening hazards from such eruptions will be primarily related to any potential explosive activity proximal to the vent. While these advance rates are slow from the perspective of personal hazards, they are 1-2 orders of magnitude faster than advance rates observed at Cordón Caulle at the end of its eruption (Tuffen et al., 2013). Only the $<3 \mathrm{~m} /$ day velocities calculated for the final weeks of eruption at $750^{\circ} \mathrm{C}$ overlap these observed velocities. The slower velocities at Cordón Caulle are also reflected in the strongly lobate morphology of these flows, a feature not observed in likely hotter and rapidly erupted Yellowstone lavas.

\section{Eruption duration constraints from surface cooling of lava}


Feasible lava flow durations are constrained by a flow's ability to advance along the surface without significant temperature decreases that would result in a large increase in viscosity. Slow or periodic magma discharge will result in compound flows built up on top of each other as the flow front solidifies and advances require new lava to breakout over this solidified front (e.g. composite lava domes Fink and Griffiths, 1998). We do not observe these features in the Summit Lake flow (Fig. 1). We thus estimate maximum thermal cooling timescales as required by the conductive cooling of a rapidly emplaced slab following the approach of Farquharson et al. (2015; see cited reference or electronic supplement 5 for equations and constants). Conductive cooling will overestimate the actual duration of lava cooling as it ignores radiative cooling at the surface and convection of precipitation through the fractured upper surface of the flow. This simplified model for the maximum duration of lava cooling, however, provides important endmember constraint on feasible solutions to the discharge-duration estimates that we make at different eruption temperatures.

We model cooling of a 100 m-thick lava section representing the margin thickness of the Summit Lake flow (see Fig. 7), which as discussed above will control the style of flow advancement (Fig. 8 and electronic supplement 5). A lava flow front will certainly cool to the point of stalling before the entire flow front cools to the solidus or glass transition temperature at $\mathrm{a} \sim 10^{12} \mathrm{~Pa} \bullet$ s viscosity $\left(\sim 720^{\circ} \mathrm{C}\right.$ following Romaine and Whittington, 2015$)$. This will occur in less than 13 years for a $750^{\circ} \mathrm{C}$ flow. Given the $>15$ year duration that we estimate for flows at $750^{\circ} \mathrm{C}$ (Table 1) this thermal model prohibits eruption and emplacement of the Summit Lake flow at $750^{\circ} \mathrm{C}$ without resulting in more complex flow morphology than we observe (e.g., Blake and Bruno, 2000). 
Discharge and duration solutions at 800 and especially $850^{\circ} \mathrm{C}$ are feasible given these cooling models (Table 1). While cooling to the glass transition provides the maximum estimate for flow front solidification, in reality viscosity increases with decreasing temperatures and will slow the front advance enough to break down application of our discharge solutions in equations 2-4. Fig. 8A shows that at any initial temperature no part of a $100 \mathrm{~m}$ thick flow front will retain its initial temperature and viscosity after about 5 years. Given a $2-5$ year duration at $800^{\circ} \mathrm{C}$, it is possible that the flow could be largely emplaced at its initial magmatic temperature and viscosity. Lava cooling will not place any constraints on emplacement in $<1$ year at $850^{\circ} \mathrm{C}$, with over $50 \%$ of the flow margin thickness remaining at its initial temperature.

\section{Implications for vent character and magma ascent rate}

Our calculated discharge rates coupled with constraints on magma ascent required for effusive eruptive character can be integrated to characterize possible vent dimensions. In order to have predominantly effusive eruption, the conduit cross-section area must be large enough and/or magma ascent rate slow enough to allow nearly complete degassing of ascending magma by gas flow through permeable networks (e.g., Woods and Koyaguchi, 1994; Melnik and Sparks, 1999). At the Soufriere Hills volcano the transition to explosive eruptions occurred for magma discharge rate of about $7-8 \mathrm{~m}^{3} / \mathrm{s}$ for a $700 \mathrm{~m}^{2}$ conduit cross-section area corresponding to $<1$ $\mathrm{cm} / \mathrm{s}$ ascent rate (Melnik and Sparks, 1999; Druitt et al., 2002). This threshold does not strongly depend on the composition and crystallinity of the magma because it is based on gas permeability of the magma that is primarily determined by bubble volume fraction. Estimates for ascent rates at effusive rhyolite eruptions are broadly similar: $0.3-0.6 \mathrm{~cm} / \mathrm{s}$ for Cordón Caulle (Castro et al., 2013) and 0.4-1.7 cm/s for Inyo Domes (Castro and Gardner, 2008). Befus et al. 
(2015b) use experimental microlite growth rates to constrain ascent rates of Yellowstone CPM magmas to $0.2-0.25 \mathrm{~cm} / \mathrm{s}$.

For Yellowstone rhyolite lavas, having ascent velocity $<1 \mathrm{~cm} / \mathrm{s}$ with an estimated temperature of $850^{\circ} \mathrm{C}$, discharge rate of $6000 \mathrm{~m}^{3} / \mathrm{s}$ will require an unrealistically large cylindrical conduit more than $800 \mathrm{~m}$ in diameter. At $800^{\circ} \mathrm{C}$ a $350 \mathrm{~m}$ diameter conduit is still required. There is no topographic evidence on the Summit Lake flow for a conduit close to this diameter, but as discussed previously the topography is consistent with eruption from an elongate fissure around $6 \mathrm{~km}$ long. In order to keep ascent rates $<1 \mathrm{~cm} / \mathrm{s}$, a fissure of this length will require a dike width of $\sim 100 \mathrm{~m}$ for the $850^{\circ} \mathrm{C}$ discharge rate (Table 1). For discharge rates associated with an $800^{\circ} \mathrm{C}$ lava, dike widths are $15 \mathrm{~m}$. In addition, and as discussed previously, discharge rates will likely be less than estimated for a point-source model given eruption from a fissure source. These smaller discharge rates will result in narrower dike widths of $40 \mathrm{~m}$ for $850^{\circ} \mathrm{C}$ and $6 \mathrm{~m}$ for $800^{\circ} \mathrm{C}$.

We are not aware of any rhyolite dike with widths $>50 \mathrm{~m}$ on earth, and there is no evidence within lavas for significant wall rock erosion required to accommodate such a large dike (Petford et al., 1993). In addition, intracaldera dikes intruding the early Yellowstone hot spot 16 Ma Tuff of Leslie Gulch or 31 Ma Crooked River Caldera linked to Yellowstone hot spot are typically 15-30 m wide (Benson and Mahood, 2016; Seligman et al., 2014). Although it is possible that the especially large-volume Summit Lake flow was fed by an unusually wide dike, we consider a $<30 \mathrm{~m}$ width more likely. Therefore, the eruption temperatures of $850^{\circ} \mathrm{C}$ or greater require geologically unfeasible dike widths or conduit diameters (Table 1). Only magmas erupted at $<850^{\circ} \mathrm{C}$ permit for ascent rates slow enough $(<1 \mathrm{~cm} / \mathrm{sec})$ to allow a dominantly effusive eruption character through geologically feasible dike geometries. 


\section{Integrating petrological observations and physical model to explain eruption triggers}

By considering both discharge implications from our viscous flow model with constraints from lava cooling and vent dimensions, we conclude a most likely eruption temperature of $\sim 800^{\circ} \mathrm{C}$ and duration of $2-5$ years. We note that this duration is strikingly similar to the timescales for preservation of quartz Ti zonation (Table 1, Fig. 6). This similarity suggests that the recharge event we propose initiates quartz rim growth also may trigger eruption of the lavas. We note other evidence for magma mixing shortly proceeding or during eruption from Loewen and Bindeman (2015) that describes $\mathrm{cm}$-scale trace element heterogeneities preserved in glass but homogenized on km-scale across the lava flow (Fig. 3) and evidence for zircon dissolution prior to eruption. Trace element diffusion through the melt would homogenize this heterogeneity over time, while Bindeman and Simakin (2014) demonstrate that thorough mixing of melt microdomains by compositional convection can easily be achieved over a several-year eruption duration.

The eruption to the surface through elongate fissures must be driven by overpressure resulting from addition of magmas during this recharge event, as illustrated in our summary diagram in Fig. 9A. Whole rock compositions suggest that magmas were water-undersaturated in a pre-eruptive magma chamber at $\sim 4 \mathrm{~km}$ depth (Fig. $2 \mathrm{~A}$ ), precluding water exsolution and buoyancy as a driving force for eruption. Magma recharge, however, will provide a direct magma overpressure that can be relieved through readily available fractures in the overlying crust provided by the vent-coincident Lava Creek tuff caldera ring fracture and regional fault lineaments that intersect the caldera (Girard and Stix, 2012). The recharge event will not only generate new melt but lead to merger of similarly generated or preexisting melt pools (Fig. 9), creating overall flow of melt to the surface. This recharge and melt redistribution model also 
provides an explanation for the lack of surface subsidence in surrounding older lava flows despite the extrusion of $10 \mathrm{~s}$ of $\mathrm{km}^{3}$ lava, as the recharge magma mass should be equivalent to the discharge. Not all recharge events may result in eruption, however as surface inflation is evident at Yellowstone via the Mallard Lake and Sour Creek resurgent domes (Christiansen, 2001).

Eruption through easily established fissures in the upper crust may be a critical component necessary for effusive eruption style. Our modeling suggests that the large-volume axisymmetric rhyolite flows of Yellowstone's CPM must be emplaced at high temperature over short time periods and at high discharge rates, driven by similar magma recharge rates. In order to maintain slower, effusive ascent rates an elongate conduit is required. The two tuff deposits in the CPM, the Cold Mountain Creek and Bluff Point, even at the same recharge rate, may have been constricted to a narrower vent away from the ring fracture resulting in $>1 \mathrm{~cm} / \mathrm{s}$ magma ascent rates, greater degrees of fragmentation during magma ascent, and subsequent deposition as pyroclastic flows (Fig. 9B). The predominance of effusive post-caldera eruptions at Yellowstone that trace ring fracture of LCT caldera (Fig 1,9) or regional fault lineaments, may be a direct result of the crustal structure allowing slow ascent through fissures. Similar structural controls are seen in post-caldera volcanism from other worldwide silicic centers such as Long Valley’s Inyo Domes (Bailey et al., 1976).

\section{Conclusions}

This study provides an integrative approach to understanding the eruption of largevolume rhyolite lavas:

(1) Integrating models of lava flow discharge, cooling, and vent character provides important constraints on how the large volume rhyolitic lavas of Yellowstone erupted. The 
eruption most likely occurred over 2-5 years at around $800^{\circ} \mathrm{C}$. Cooler eruption temperatures require emplacement durations $>10$ years slow enough for the flow front to solidify resulting in compound flow morphology. Higher temperatures require geologically unreasonable dike widths $>50 \mathrm{~m}$.

(2) Eruption of Summit Lake and other large volume Yellowstone rhyolites was accommodated through fissures of 4-6 km length, coincident with regional fault structures that intersect the ring fracture of Lava Creek Tuff caldera and the eruption foci of other CPM lava flows. These pathways allowed slower magma ascent to prevent explosive eruption despite high discharge rates. The fissure-style eruptions that we describe here are a critical component of effusive eruption of the Yellowstone-Snake River Plain system and in similar hot-dry rhyolites worldwide.

(3) An abrupt crystal growth event occurred on a timescale remarkably similar to the estimated eruption duration and extrusion rates. We suggest that this growth was triggered by magma assembly into the upper reservoir via influx of a geochemically similar rhyolite magma leading to nearly contemporaneous magma transport and mixing and overpressure that triggered and maintained the eruption.

(4) At a given recharge rate, when large preexisting fissures are not available, eruption may proceed through narrower conduits with high ascent rates that will promote fragmentation and result in deposition of pyroclastic flows instead of lavas. This can explain effusive vs. explosive eruptions of Yellowstone and worldwide.

(5) Embayed quartz textures result from growth rather than dissolution, and this interpretation may prove useful in understanding other silicic volcanic systems worldwide. 
While these observations have focused on Yellowstone's rhyolite lavas, our approach of examining crystal textures with vent characteristic and dynamics can improve understanding of rhyolitic lava flows elsewhere. Our modeling provides "top-down" constraints on magmatic processes and can be adapted in future work to provide better models of rhyolitic lava flow behavior.

\section{Acknowledgments}

We thank Z. Severin for help in textural characterization, K. Watts, R. Weber, and D. Colón for assistance during fieldwork, F. Tepley for assistance with CL-imaging, J. Choinard for assistance with quartz Ti analysis, J.S. Lackey for providing XRF analyses, and B. VanderBeek for assistance applying cooling models. Editorial handling by T. Mather and comments from R.L. Christiansen and anonymous reviewers helped to improve this manuscript as well as discussions with M. Myers and P. Wallace. This project was funded by NSF grant EAR/CAREER-844772 to I.N.B., a University of Oregon Meierjurgen Fellowship and RSCF grant 14-17-00520 to O.E.M.

\section{References}

Anderson, A.T.J., 1991. Hourglass inclusions: Theory and application to the Bishop Rhyolitic Tuff. American Mineralogist 76, 530-547.

Bailey, R.A., Dalrymple, G.B., Lanphere, M.A., 1976. Volcanism, structure, and geochronology of Long Valley Caldera, Mono County, California. Journal of Geophysical Research 81, 725-744.

Balmforth, N.J., Craster, R.V., 2000. Dynamics of cooling domes of viscoplastic fluid. Journal of Fluid Mechanics 422, 225-248. 
Befus, K.S., Gardner, J.E., 2016. Magma storage and evolution of the most recent effusive and explosive eruptions from Yellowstone Caldera. Contributions to Mineralogy and Petrology $171,30$.

Befus, K.S., Watkins, J., Gardner, J.E., Richard, D., Befus, K.M., Miller, N.R., Dingwell, D.B., 2015a. Spherulites as in-situ recorders of thermal history in lava flows. Geology 43, 647650.

Befus, K.S., Manga, M., Gardner, J.E., Williams, M., 2015b. Ascent and emplacement dynamics of obsidian lavas inferred from microlite textures. Bulletin of Volcanology 77, 88.

Benson, T.R., Mahood, G.A., 2016. Geology of the Mid-Miocene Rooster Comb Caldera and Lake Owyhee Volcanic Field, eastern Oregon: silicic volcanism associated with Grande Ronde flood basalt. Journal of Volcanology and Geothermal Research 309, 96-117.

Bindeman, I.N., Lowenstern, J.B., 2016. Low- $\delta$ D hydration rinds in Yellowstone perlites record rapid syneruptive hydration during glacial and interglacial conditions. Contributions to Mineralogy and Petrology. doi: 10.1007/s00410-016-1293-1.

Bindeman, I.N., Melnik, O.E., 2016. Zircon survival, rebirth and recycling during crustal melting, magma crystallization, and mixing based on numerical modelling. Journal of Petrology, 57, 437-460. doi:10.1093/petrology/egw013

Bindeman, I.N., Simakin, A.G., 2014. Rhyolites--Hard to produce, but easy to recycle and sequester: Integrating microgeochemical observations and numerical models. Geosphere 10, 930-957.

Bindeman, I.N., Valley, J.W., 2001. Low- $\delta^{18}$ O rhyolites from Yellowstone: Magmatic evolution based on analyses of zircons and individual phenocrysts. Journal of Petrology 42, 14911517. 
Blake, S., 1990. Viscoplastic models of lava domes. In: Fink, J.H. (Ed.), Lava Flows and Domes: Emplacement Mechanisms and Hazard Implications. In: IAVCEI Proceedings of Volcanology vol. 2. Springer, pp. 88-128.

Blake, S., Bruno, B.C., 2000. Modelling the emplacement of compound lava flows. Earth and Planetary Science Letters 184, 181-197.

Blundy, J., Cashman, K., 2001. Ascent-driven crystallization of dacite magmas at Mount St. Helens, 1980-1986. Contributions to Mineralogy and Petrology 140, 631-650.

Cabane, H., Laporte, D., Provost, A., 2001. Experimental investigation of the kinetics of Ostwald ripening of quartz in silicic melts. Contributions to Mineralogy and Petrology 142, 361373.

Castro, J.M., Bindeman, I.N., Tuffen, H., Schipper, C.I., 2014. Explosive origin of silicic lava: Textural and $\delta \mathrm{D}-\mathrm{H}_{2} \mathrm{O}$ evidence for pyroclastic degassing during rhyolite effusion. Earth and Planetary Science Letters 405, 52-61.

Castro, J.M., Dingwell, D.B., 2009. Rapid ascent of rhyolitic magma at Chaitén volcano, Chile. Nature 461, 780-783.

Castro, J.M., Gardner, J.E., 2008. Did magma ascent rate control the explosive-effusive transition at the Inyo volcanic chain, California? Geology 36, 279-282.

Castro, J.M., Schipper, C.I., Mueller, S.P., Militzer, A.S., Amigo, A., Parejas, C.S., Jacob, D., 2013. Storage and eruption of near-liquidus rhyolite magma at Cordón Caulle, Chile. Bulletin of Volcanology 75, 702.

Cherniak, D., Watson, E., Wark, D.A., 2007. Ti diffusion in quartz. Chemical Geology 236, 6574. 
Christiansen RL, Blank HR, 1972. Volcanic stratigraphy of the Quaternary rhyolite plateau in Yellowstone National Park. US Geological Survey Professional Paper 729-B, 1-18.

Christiansen, R.L., 2001. The Quaternary and Pliocene Yellowstone Plateau volcanic field of Wyoming, Idaho, and Montana. US Geological Survey Professional Paper 729-G, 1-145.

Christiansen, R.L., Lowenstern, J.B., Smith, R.B., Heasler, H., Morgan, L.A., Nathenson, M., Mastin, L.G., Muffler, L.J.P., Robinson, A.J.E., 2007. Preliminary Assessment of Volcanic and Hydrothermal Hazards in Yellowstone National Park and Vicinity. US Geological Survey Open-File Report 2007-1071, 1-94.

de Silva, S., Self, S., Francis, P.W., Drake, R.E., Carlos, R.R., 1994. Effusive silicic volcanism in the Central Andes: The Chao dacite and other young lavas of the Altiplano-Puna Volcanic Complex. Journal of Geophysical Research 99, 17805-17825.

Druitt, T.H., Young, S.R., Baptie, B., Bonadonna, C., Calder, E.S., Clarke, A.B., Cole, P.D., Harford, C.L., Herd, R.A., Luckette, R., Ryan, G., Voight, B., 2002. Episodes of cyclic Vulcanian explosive activity with fountain collapse at Soufriere Hills Volcano, Montserrat. Geological Society of London Memoirs 21, 281-306.

Farquharson, J.I., James, M.R., Tuffen, H., 2015. Examining rhyolite lava flow dynamics through photo-based 3D reconstructions of the 2011-2012 lava flowfield at CordónCaulle, Chile. Journal of Volcanology and Geothermal Research 304, 336-348.

Fink, J.H., Griffiths, R.W., 1998. Morphology, eruption rates, and rheology of lava domes: Insights from laboratory models. Journal of Geophysical Research 103, 527-545.

Girard, G., Stix, J., 2010. Rapid extraction of discrete magma batches from a large differentiating magma chamber: the Central Plateau Member rhyolites, Yellowstone Caldera, Wyoming. Contributions to Mineralogy and Petrology 160, 441-465. 
Girard, G., Stix, J., 2012. Future volcanism at Yellowstone caldera: Insights from geochemistry of young volcanic units and monitoring of volcanic unrest. GSA Today 22, 4-10.

Graham, C.M., Harmon, R.S., Sheppard, S.M.F., 1984. Experimental hydrogen isotope studies: hydrogen isotope exchange between amphibole and water. American Mineralogist 69, 128-138.

Gregg, P.M., Grosfils, E.B., de Silva, S.L., 2015. Catastrophic caldera-forming eruptions II: The subordinate role of magma buoyancy as an eruption trigger. Journal of Volcanology and Geothermal Research 305, 100-113.

Gualda, G.A.R., Ghiroso, M.S., Lemons, R.V., Carley, T.L., 2012a. Rhyolite-MELTS: a modified calibration of MELTS optimized for silica-rich fluid-bearing magmatic systems. Journal of Petrology 53, 875-890.

Gualda, G.A.R., Pamukcu, A.S., Ghiorso, M.S., Anderson, A.T., Sutton, S.R., Rivers, M.L., 2012b. Timescales of Quartz Crystallization and the Longevity of the Bishop Giant Magma Body. PLoS ONE 7, e37492.

Hidaka, M., Goto, A., Umino, S., Fujita, E., 2005. VTFS project: Development of the lava flow simulation code LavaSIM with a model for three-dimensional convection, spreading, and solidification. Geochemistry, Geophysics, Geosystems 6, Q07008, doi:10.1029/2004GC000869.

Hildreth, W., Christiansen, R.L., O'Neil, J.R., 1984. Catastrophic isotopic modification of rhyolitic magma at times of caldera subsidence, Yellowstone Plateau volcanic field. Journal of Geophysical Research 89, 8339-8369.

Hildreth, W., Moorbath, S., 1988. Crustal contributions to arc magmatism in the Andes of central Chile. Contributions to Mineralogy and Petrology 98, 455-489. 
Holtz, F., Pichavant, M., Barbey, P., Johannes, W., 1992. Effects of $\mathrm{H}_{2} \mathrm{O}$ on liquidus phase relations in the haplogranite system at 2 and 5 kbar. American Mineralogist 77, 12231241.

Huppert, H.E., 1982. The propagation of two-dimensional and axisymmetric viscous gravity currents over a rigid horizontal surface. Journal of Fluid Mechanics 121, 43-58.

Huppert, H.E., Shepherd, J.B., Sigurdsson, H., Sparks, R.S.J., 1982. On lava dome growth, with application to the 1979 lava extrusion of the Soufrière of St. Vincent. Journal of Volcanology and Geothermal Research 14, 199-222.

Huppert, H.E., Sparks, R.S.J., 1988. The generation of granitic magmas by intrusion of basalt into the continental crust. Journal of Petrology 29, 599-624.

Lemmlein, C.G., 1930. Corrosion and regeneration of quartz phenocrysts in quartz porphries. Doklady Akademii nauk SSR 13, 341-344.

Lescinsky, D.T., Fink, J.H., 2000. Lava and ice interaction at stratovolcanoes: use of characteristic features to determine past glacial extents and future volcanic hazards. Journal of Geophysical Research 105, 23711-23726.

Licciardi, J. M., Pierce, K. L., 2008. Cosmogenic exposure-age chronologies of Pinedale and Bull Lake glaciations in greater Yellowstone and the Teton Range, USA. Quaternary Science Reviews 27, 814-831.

Lister, J.R., 1992. Viscous flows down and inclined plane from point and line sources. Journal of Fluid Mechanics 242, 631-653.

Loewen, M.W., Bindeman, I.N., 2015. Oxygen isotope and trace element evidence for threestage petrogenesis of the youngest episode (260-79 ka) of Yellowstone rhyolitic 
volcanism. Contributions to Mineralogy and Petrology 170, 39, doi: 10.1007/s00410015-1189-5.

Loewen, M.W., Bindeman, I.N., 2016. Oxygen isotope thermometry reveals high magmatic temperatures and short residence times in Yellowstone and other hot-dry rhyolites compared to cold-wet systems. American Mineralogist 101, 1222-1227, doi: 10.2138/am2016-5591.

Manley, C.R., 1996. Physical volcanology of a voluminous rhyolite lava flow: The Badlands lava, Owyhee Plateau, southwestern Idaho. Journal of Volcanology and Geothermal Research, 71, 129-153.

Melnik, O., Sparks, R.S.J., 1999. Nonlinear dynamics of lava dome extrusion. Nature 402, 37-41.

Newman, S., Epstein, S., Stolper, E., 1988. Water, carbon dioxide, and hydrogen isotopes in glasses from the ca. 1340 A.D. eruption of the Mono Craters, California: Constraints on degassing phenomena and initial volatile content. Journal of Volcanology and Geothermal Research, 35, 75-96.

Newman, S., Lowenstern, J.B., 2002. VolatileCalc: a silicate melt- $\mathrm{H}_{2} \mathrm{O}-\mathrm{CO}_{2}$ solution model written in Visual Basic for excel. Computers and Geosciences 28, 597-604.

Pallister, J.S., Diefenbach, A.K., Burton, W.C., Munoz, J., Griswold, J.P., Lara, L.E., Lowenstern, J.B., Valenzuela, C.E., 2013. The Chaitén rhyolite dome: Eruption sequence, lava dome volumes, rapid effusion rates and source of the rhyolite magma. Andean Geology 40, 277-294.

Pamukcu, A.S., Gualda, G.A.R, Bégué, F., Gravley, D.M., 2015. Melt inclusion shapes: Timekeepers of short-lived giant magma bodies. Geology 43, 947-950. 
Petford, N., Kerr, R.C., Lister, J.R., 1993. Dike transport of granitoid magmas. Geology 21, 845848.

Pierce, K.L., Obradovich, J.D., 1976. Obsidian hydration dating and correlation of Bull Lake and Pinedale glaciations near West Yellowstone, Montana. Geological Society of American Bulletin 87, 703-710.

Roedder, E., 1979. Origin and significance of magmatic inclusions. Bulletin of Mineralogy 102, 487-510.

Romine, W.L., Whittington, A.G., 2015, A simple model for the viscosity of rhyolites as a function of temperature, pressure, and water content. Geochimica et Cosmochimica Acta $170,281-300$.

Ryan, W., Carbotte, S.M., Coplan, J.O., O'Hara, S., Melkonian, A., Arko, R., Weissel, R.A., Ferrini, V., Goodwillie, A., Nitsche, F., Bonczkowski, J., Zemsky, R., 2009. Global Multi-Resolution Topography synthesis. Geochemistry, Geophysics, Geosystems 10, Q03014.

Saubin, E., Tuffen, H., Gurioli, L., Own, J., Castro, J.M., Berlo, K., McGowan, E.M., Schiper, C.I., Wehbe, K., 2016. Conduit dynamics in transitional rhyolitic activity recorded by tuffisite vein textures from the 2008-2009 Chaitén eruption. Frontiers in Earth Sciences 4, $59 \mathrm{p}$.

Schipper, C.I., Castro, J.M., Tuffen, H., James, M.R., How, P., 2013. Shallow vent architecture during hybrid explosive-effusive activity at Cordón Caulle (Chile, 2011-12): Evidence from direct observations and pyroclast textures. Journal of Volcanology and Geothermal Research 262, 25-37.

Self, S., Blake, S., (2008). Consequences of explosive supereruptions. Elements 4, 41-46. 
Seligman, A.N., Bindeman, I.N., McClaughry, J., Stern, R.A., Fisher, C., 2014. The earliest low and high $\delta^{18} \mathrm{O}$ caldera-forming eruptions of the Yellowstone plume: implications for the 30-40 Ma Oregon calderas and speculations on plume-triggered delaminations. Frontiers in Earth Science 2, 34.

Stelten, M.E., Cooper, K.M., Vazquez, J.A., Calvert, A.T., Glessner, J.J.G., 2015. Mechanisms and timescales of generating eruptible rhyolitic magmas at Yellowstone Caldera from zircon and sanidine geochronology and geochemistry. Journal of Petrology 56, $1607-$ 1642.

Swanson, S.E., Fenn, P.M., 1986. Quartz crystallization in igneous rocks. American Mineralogist 71, 331-342.

Taylor, B.E., 1991. Degassing of Obsidian Dome rhyolite, Inyo volcanic chain, California. In: Taylor Jr., H.P., O’Neil, J.R., Kaplan, J.R. (Eds.), Stable Isotope Geochemistry: A Tribute to Samual Epstein. In: Geochemical Society Special Publication, vol. 3. The Geochemical Society, San Antonio, TX, pp. 339-353.

Till, C.B., Vazquez, J.A., Boyce, J.W., 2015. Months between rejuvenation and volcanic eruption at Yellowstone caldera, Wyoming. Geology 43, 695-698.

Tuffen, H., James, M.R., Castro, J.M., Schipper, I., 2013. Exceptional mobility of an advancing rhyolitic obsidian flow at Cordón Caulle volcano, Chile. Nature Communications 4, 2709.

Vazquez, J.A., Kyriazis, S.F., Reid, M.R., Sehler, R.C., Ramos, F.C., 2009. Thermochemical evolution of young rhyolites at Yellowstone: Evidence for a cooling but periodically replenished postcaldera magma reservoir. Journal of Volcanology and Geothermal Research 188, 186-196. 
Wadge, G., 1981. The variation of magma discharge during basaltic eruptions. Journal of

Volcanology and Geothermal Research 11, 139-168.

Wark, D.A., Hildreth, W., Spear, F., Cherniak, D., Watson, E.B., 2007. Pre-eruption recharge of the Bishop magma system. Geology 35, 235-238.

Watts, K.E., Bindeman, I.N., Schmitt, A.K., 2012. Crystal scale anatomy of a dying supervolcano: an isotope and geochronology study of individual phenocrysts from voluminous rhyolites of the Yellowstone caldera. Contributions to Mineralogy and Petrology 164, 45-67.

Woods, A.W., Koyaguchi, T., 1994. Transitions between explosive and effusive eruptions of silicic magmas. Nature 370, 641-644.

\section{Tables and Figure Captions}

Table 1. Timescale estimates the Summit Lake rhyolite lava at different eruption surface temperatures and erupted via a circular conduit or elongate fissure.

\begin{tabular}{|c|c|c|c|c|c|}
\hline Temperature $\left({ }^{\circ} \mathbf{C}\right)$ & 750 & 775 & 800 & 825 & 850 \\
\hline \multicolumn{6}{|l|}{ Ti-in-quartz diffusion (years): } \\
\hline 08YS-1 & 96 & 44 & 21 & 11 & 5 \\
\hline 08YS-20 & 15 & 7 & 3 & 2 & 1 \\
\hline \multicolumn{6}{|l|}{ Gravity driven flow (years): } \\
\hline Point source ${ }^{a}$ & $16(120)$ & $5(37)$ & 2 (12) & $0.8(5)$ & $0.3(2)$ \\
\hline Elongate fissure $^{\mathrm{b}}$ & $39(290)$ & $13(92)$ & $5(31)$ & $2(11)$ & $0.8(4)$ \\
\hline \multicolumn{6}{|l|}{ Discharge Rate $\left(\mathbf{m}^{3} / \mathbf{s}\right)$ : } \\
\hline Point source ${ }^{a}$ & $120(16)$ & $340(50)$ & $920(150)$ & $2400(400)$ & $5800(1100)$ \\
\hline Elongate fissure $^{\mathrm{b}}$ & $46(6)$ & $140(20)$ & $370(60)$ & $950(160)$ & $2300(420)$ \\
\hline Conductive cooling (years): ${ }^{c}$ & \multicolumn{2}{|c|}{$\begin{array}{l}<14 \\
\text { solid before emplacement }\end{array}$} & \multicolumn{3}{|c|}{$\begin{array}{l}<\mathbf{1 8} \\
\text { easily emplaced before solid }\end{array}$} \\
\hline \multicolumn{6}{|l|}{ Dike width $(\mathbf{m}){ }^{\text {d }}$} \\
\hline Point source ${ }^{a}$ & $2(0.3)$ & $6(1)$ & $15(2)$ & $40(7)$ & $100(18)$ \\
\hline Elongate fissure ${ }^{\mathrm{b}}$ & $1(0.1)$ & $2(0.3)$ & $6(1)$ & $16(3)$ & $39(7)$ \\
\hline
\end{tabular}

${ }^{a}$ Point source calculated with eqn. $3, V=57 \mathrm{~km}^{3}, \mathrm{r}=11.3 \mathrm{~km}$, and viscosity from Romaine and Whittington (2015) using measured Summit Lake whole rock composition and $0.2 \mathrm{wt} . \%$ water $(0.1 \mathrm{wt} . \%$ water shown for reference in parentheses). ${ }^{b}$ Elongate fissure calculated eqn. 4 using the same inputs but a source fissure length of $14.8 \mathrm{~km}$. Elongate fissure solutions provide overestimates of duration with best duration estimates closer to the point source solution. ${ }^{\mathrm{c}}$ Cooling model of a $100 \mathrm{~m}$ thick section representing the flow margin. Times are for complete cooling to the glass transition temperature, while stalling of the front and resulting flow breakouts, not observed at Summit Lake, will occur earlier than the time indicated here. ${ }^{\mathrm{d}}$ Dike widths calculated assuming a rectangular dike cross section, a fissure length of $6 \mathrm{~km}$, and an ascent rate of $1 \mathrm{~cm} / \mathrm{s}$. 
Fig. 1. (A) Overview map outlining Yellowstone Central Plateau Member rhyolite lava flows, vent locations, and the Lava Creek Tuff caldera margin. (B) Elevation map of the Summit Lake and nearby lavas. Approximate symmetrical dotted circle in line with the A-A' section has the same area $\left(400 \mathrm{~km}^{2}\right)$ as the mapped flow surface area. Thin flow morphology lines are shown from Christiansen (2001). A potential $6 \mathrm{~km}$ long fissure, is indicated by a thick line that focused to a final vent location at the intersection of A-A', B-B', and C-C'. Topography is from $10 \mathrm{~m}$ resolution ASTER data plotted using GeoMapApp (Ryan et al., 2009). (C) Detailed elevation map for the surface of the Summit Lake flow, with measured river incision depths.

Fig. 2. (A) Whole rock compositions plotted on the quartz-feldspar ternary phase diagram. Whole rock compositions for Summit Lake and all other CPM lava flows plot between 100-200 MPa cotectic lines and are consistent with water-undersaturated cotectic minima from Holtz et al. (1992). Compositions are plotted to include anorthite influence following Blundy and Cashman (2001), and water-saturated curves are also from this study. (B) Rhyolite-MELTS model of the average Summit Lake whole rock composition at $100 \mathrm{MPa}$, QFM oxygen fugacity, and variable initial water concentrations. Quartz and sanidine are near-liquidus phases while plagioclase, not observed at Summit Lake, does not crystallize until the eutectic at $770-780^{\circ} \mathrm{C}$ along with water saturation. Increasing pressure to $200 \mathrm{MPa}$ lowers the liquidus temperature by $\sim 50^{\circ} \mathrm{C}$ and the eutectic temperature by $\sim 25^{\circ} \mathrm{C}$.

Fig. 3. Compositions of sampled collected in a transect from the vent to margin of the Summit Lake flow. Earliest erupted samples are found at the flow margin and latest erupted closest to the vent. No $>95 \%$ confidence trends are seen between these and other (see electronic supplement 1) 
compositional parameters and distance from vent. Total crystallinity and oxygen isotope values may increase and decrease, respectively, towards the flow margin. Quartz cores have consistently higher Ti than quartz rims, and matrix glass has higher trace element concentrations for all elements except $\mathrm{Nb}$ (shown here), $\mathrm{Rb}, \mathrm{Pb}$, and $\mathrm{U}$.

Fig. 4. (A) Water concentrations and hydrogen isotope ratios in obsidian glass for Summit Lake and other Central Plateau Member rhyolites. Most glass compositions are low water ( 0.1 wt.\%) with $\delta \mathrm{D}$ of -110 to $-140 \%$ consistent with closed followed by near-surface open system degassing. Initial water concentrations and $\delta \mathrm{D}$ based on amphibole values from the Lava Creek Tuff (LCT) amphibole-melt fractionation of -30\% (Graham et al. 1984). Degassing lines calculated following Taylor (1991).

Fig. 5. CL-images of quartz phenocrysts in thin sections from samples collected across the Summit Lake flow. No significant changes in phenocryst morphology or zoning are indicated in early to late erupted samples, except for more common occurrence of broken crystals in the earliest erupted sample (08YS-20). Bright-CL cores are common (>50\% of examined phenocrysts), along with hexagonal faceted external morphology, and embayments. Some embayments have extremely narrow necks (C, D, E, M, see arrows in sketches) that can be formed by annealing of rapid, skeletal growth features, and are difficult to imagine forming from dissolution processes. Crystal D resembles a classic skeletal growth pattern, with internal CLzoning reflecting rapid growth at crystal corners followed by annealing and trapping of melt inclusions within embayments. Only three crystals are clearly anhedral in form (F, B, O) and these may result from the angle of crystal sectioning. Interpreted sketches of selected 
phenocrysts are shown at the bottom, with bright-CL cores in light grey, rims in dark-grey, and surrounding melt, melt embayments, and melt inclusions in white.

Fig. 6. Strong zoning present in Summit Lake quartz crystals is characterized by a sharp transition between high-Ti cores and low-Ti rims in both late (A) and early (B) erupted samples. Calibrating Cathode Luminescence (CL) greyscale to electron microprobe determinations (following Wark et al., 2007) resolve a $<7 \mu \mathrm{m}$ boundary between core and rim. Blue dashed curve is best-fit diffusion model following the approach of Gualda et al. (2012). Using temperature dependent diffusion coefficients (Cherniak et al., 2007), this line represents a diffusive duration of 96, 21, and 5 years for (A) and 15, 3, and 1 year for (B) at 750, 800, and $850^{\circ} \mathrm{C}$, respectively.

Fig. 7. Cross-sections from Fig. 1. Surface topography is shown in grey. The maximum potential average slopes (m) are shown in grey dashed lines. The dashed black line shows a more likely inferred topography below the Summit Lake Flow that can explain external flow morphology. The black dotted line is a shape predicted by a model of viscous flow over a horizontal surface, from eqn. 1. Final vent location is shown with a star, and the length of our proposed fissure-style vent is shown with a rectangle along $\mathrm{C}-\mathrm{C}^{\prime}$.

Fig. 8. Conductive cooling model for a $100 \mathrm{~m}$ thick lava flow margin (see Fig. 6) following the approach Farquharson et al. (2015). Solidification of the flow margin will control flow morphology and the occurrence of lava breakouts which are not observed for Summit Lake (see Fig. 1). (A) Compares the minimum viscosity over time. A conductive cooling front will reach 
the center of a $100 \mathrm{~m}$ thick section after about 5 years for any initial temperature, resulting in sharp increases in viscosity. (B) The proportion of flow below the glass transition temperature $\left(\mathrm{T}_{\mathrm{g}}\right.$ ) increases through time, reaching $100 \%$ by $\sim 13$ years for a $750^{\circ} \mathrm{C}$ initial temperature, 18 years for $800^{\circ} \mathrm{C}$, and 22 years for $850^{\circ} \mathrm{C}$.

Fig. 9. (A) Synthesis diagram of the eruption of large volume rhyolite lavas. 1. Remelting and merger of hot near-solidus intracaldera rhyolitic batches; high-Ti cores of quartz crystals are inherited from crystalline remnants of earlier CPM magmatic episodes or remobilized from a near-solidus crystal mush. Pyroxene and magnetite crystallize here at near-liquidus temperatures $>900^{\circ} \mathrm{C}$, and preservation of magnetite oxygen isotope compositions constrains the melting event to occur $<\sim 10^{3}$ years from eruption (Loewen and Bindeman, 2016). 2. A pre-eruptive, perhaps ephemeral, magma body is formed at shallow depths from amalgamation of generated melts via dikes and sills and results in lower $<850^{\circ} \mathrm{C}$ temperatures and saturation of accessory minerals zircon and chevkinite, consistent with lower temperature zircon crystallization and geochemical trends observed within individual CPM units. Quartz carried within recharge magmas are undercooled resulting in hopper-style rim growth at the same composition/temperature as low-Ti phenocrysts. The sharpest observed core-rim boundaries constrain the final shallow amalgamation of magmas to within years to decades of eruption and quenching. 3. Eruption proceeds due to overpressure upon melt refill and batch merger (stages 1-2), and volatile exsolution is only achieved during ascent within conduit and triggers microlite crystallization. Eruption proceeds along elongate fissures tracking the LCT caldera boundary (Fig. 1) and likely at the edge of the magma body as is predicted from stress fields in overpressured magma bodies modeled by Bindeman and Simakin (2014; indicated by colors and arrows in the top part of 
diagram). 4. Gravity-driven flow at $\sim 800^{\circ} \mathrm{C}$ will occur in 2-5 years. Spherulite growth occurs during subsequent subsolidus cooling (Befus et al., 2015a). (B) The origin of effusive vs explosive rhyolite eruptions of Yellowstone in response to episodes of high recharge and merger rates. Voluminous lavas: high discharge rate $(\mathrm{Q})$ along zones of preexisting crustal weakness, such as along the caldera ring fractures, results from low ascent velocity through large crosssection dikes (LxW). Tuff eruptions: ascent is via more constricted conduits (smaller LxW) and leads to higher ascent rate at equal discharge $\mathrm{Q}$, leading to magma vesiculation and fragmentation during ascent. Diagram is not to scale. 


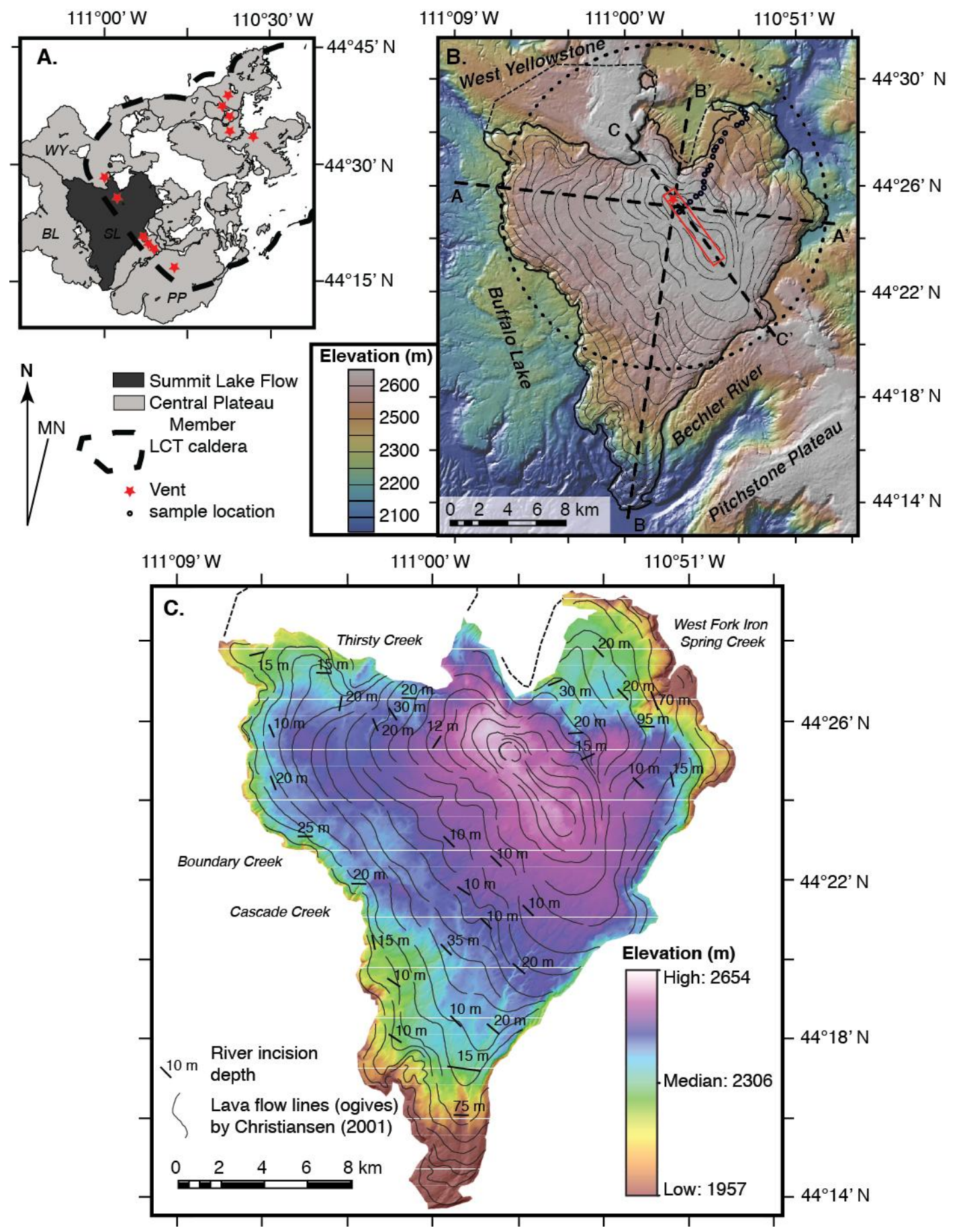

Fig. 1. (A) Overview map outlining Yellowstone Central Plateau Member rhyolite lava flows, vent locations, and the Lava Creek Tuff caldera margin. (B) Elevation map of the Summit Lake and nearby lavas. Approximate symmetrical dotted circle in line with the A-A' section has the same area $\left(400 \mathrm{~km}^{2}\right)$ as the mapped flow surface area. Thin flow morphology lines are shown from Christiansen (2001). A potential $6 \mathrm{~km}$ long fissure, is indicated by a thick line that focused to a final vent location at the intersection of A-A', B-B', and C-C'. Topography is from $10 \mathrm{~m}$ resolution ASTER data plotted using GeoMapApp (Ryan et al., 2009). (C) Detailed elevation map for the surface of the Summit Lake flow, with measured river incision depths. 


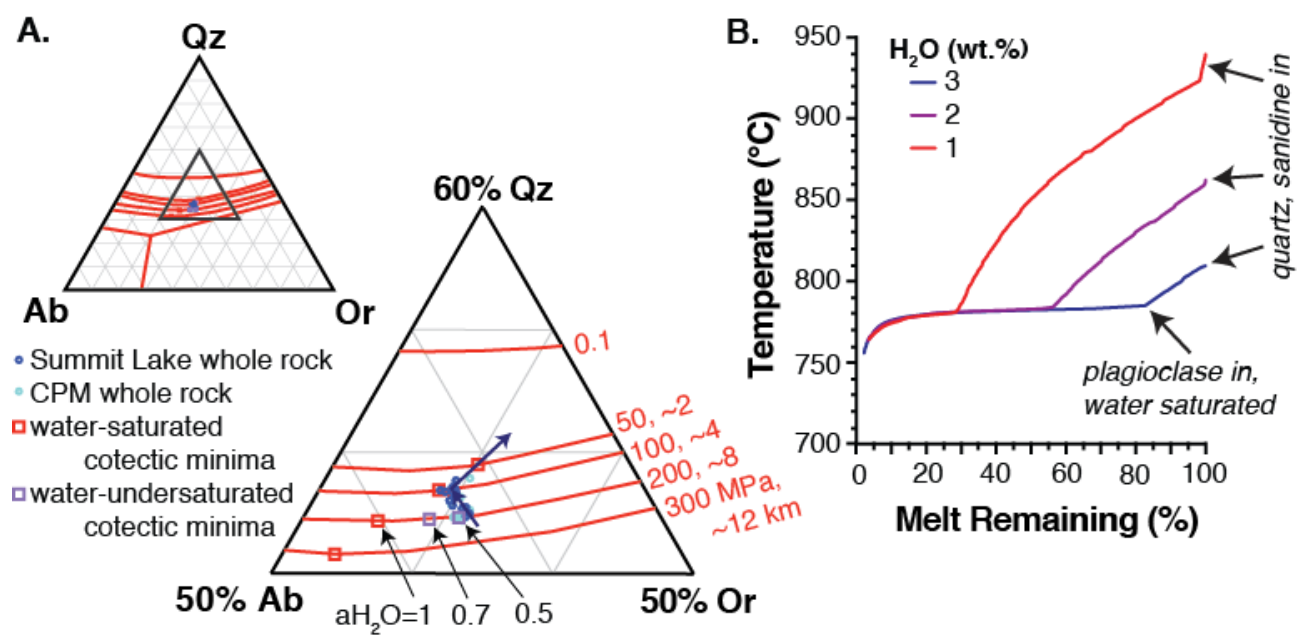

Fig. 2. (A) Whole rock compositions plotted on the quartz-feldspar ternary phase diagram. Whole rock compositions for Summit Lake and all other CPM lava flows plot between 100-200 MPa cotectic lines and are consistent with water-undersaturated cotectic minima from Holtz et al. (1992). Compositions are plotted to include anorthite influence following Blundy and Cashman (2001), and water-saturated curves are also from this study. (B) Rhyolite-MELTS model of the average Summit Lake whole rock composition at $100 \mathrm{MPa}$, QFM oxygen fugacity, and variable initial water concentrations. Quartz and sanidine are near-liquidus phases while plagioclase, not observed at Summit Lake, does not crystallize until the eutectic at $770-780^{\circ} \mathrm{C}$ along with water saturation. Increasing pressure to $200 \mathrm{MPa}$ lowers the liquidus temperature by $\sim 50^{\circ} \mathrm{C}$ and the eutectic temperature by $\sim 25^{\circ} \mathrm{C}$. 

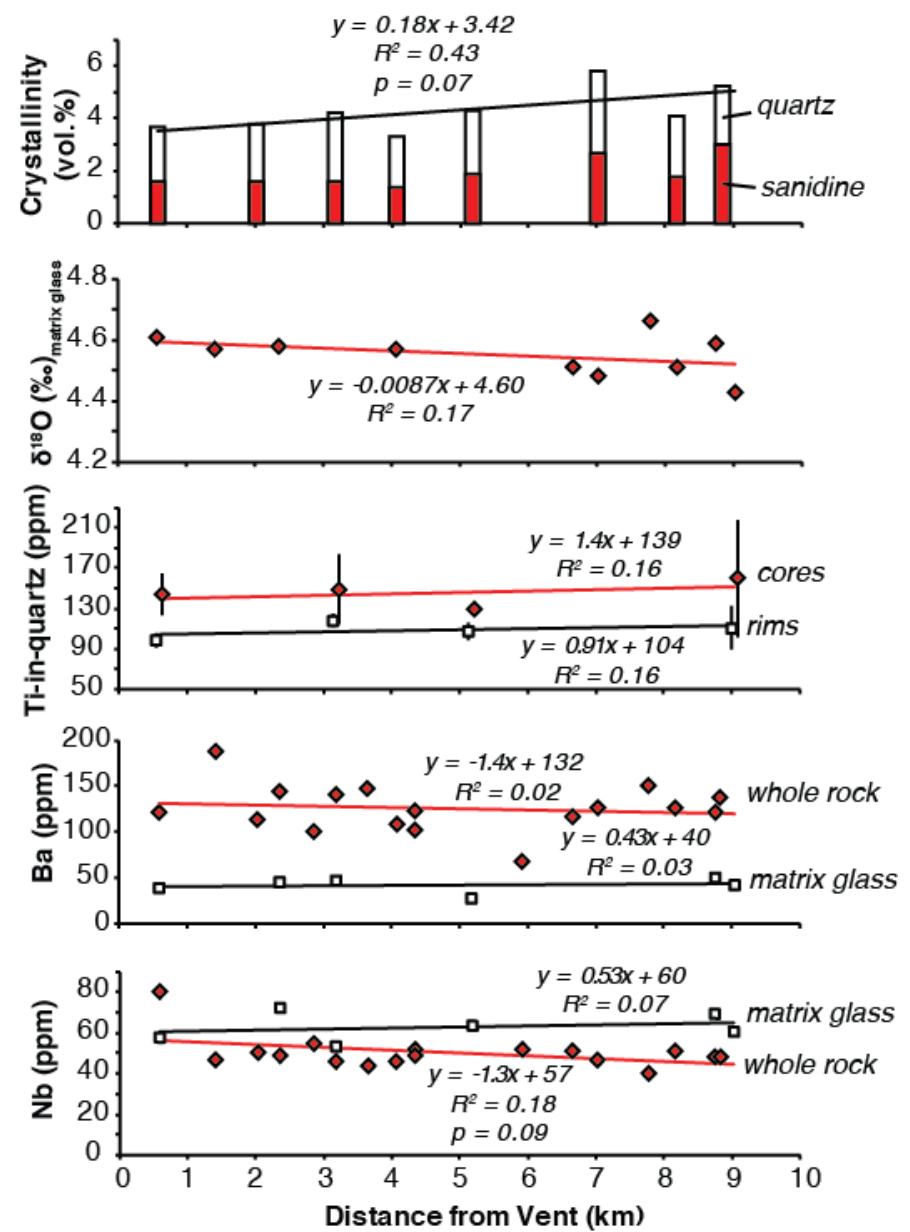

Fig. 3. Compositions of sampled collected in a transect from the vent to margin of the Summit Lake flow. Earliest erupted samples are found at the flow margin and latest erupted closest to the vent. No $>95 \%$ confidence trends are seen between these and other (see electronic supplement 1) compositional parameters and distance from vent. Total crystallinity and oxygen isotope values may increase and decrease, respectively, towards the flow margin. Quartz cores have consistently higher Ti than quartz rims, and matrix glass has higher trace element concentrations for all elements except $\mathrm{Nb}$ (shown here), $\mathrm{Rb}, \mathrm{Pb}$, and $\mathrm{U}$. 


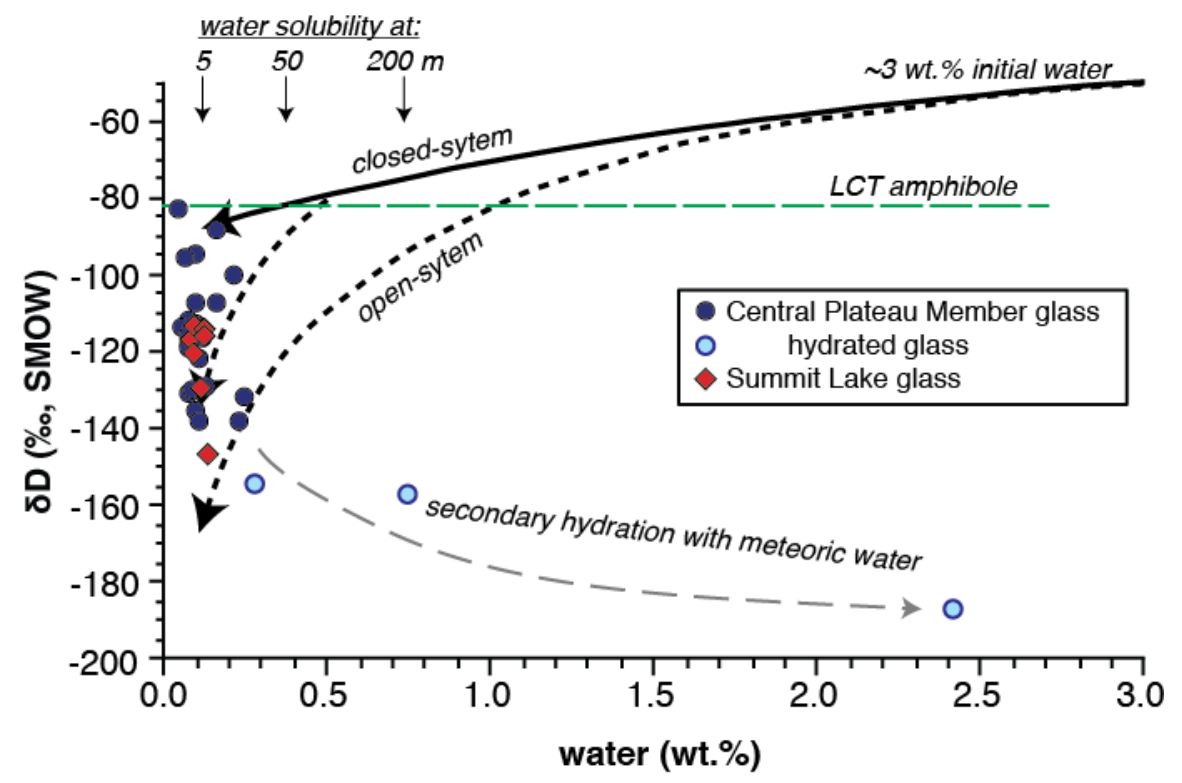

Fig. 4. (A) Water concentrations and hydrogen isotope ratios in obsidian glass for Summit Lake and other Central Plateau Member rhyolites. Most glass compositions are low water ( 0.1 wt.\%) with $\delta \mathrm{D}$ of -110 to $-140 \%$ consistent with closed followed by near-surface open system degassing. Initial water concentrations and $\delta \mathrm{D}$ based on amphibole values from the Lava Creek Tuff (LCT) amphibole-melt fractionation of -30\%o (Graham et al. 1984). Degassing lines calculated following Taylor (1991). 

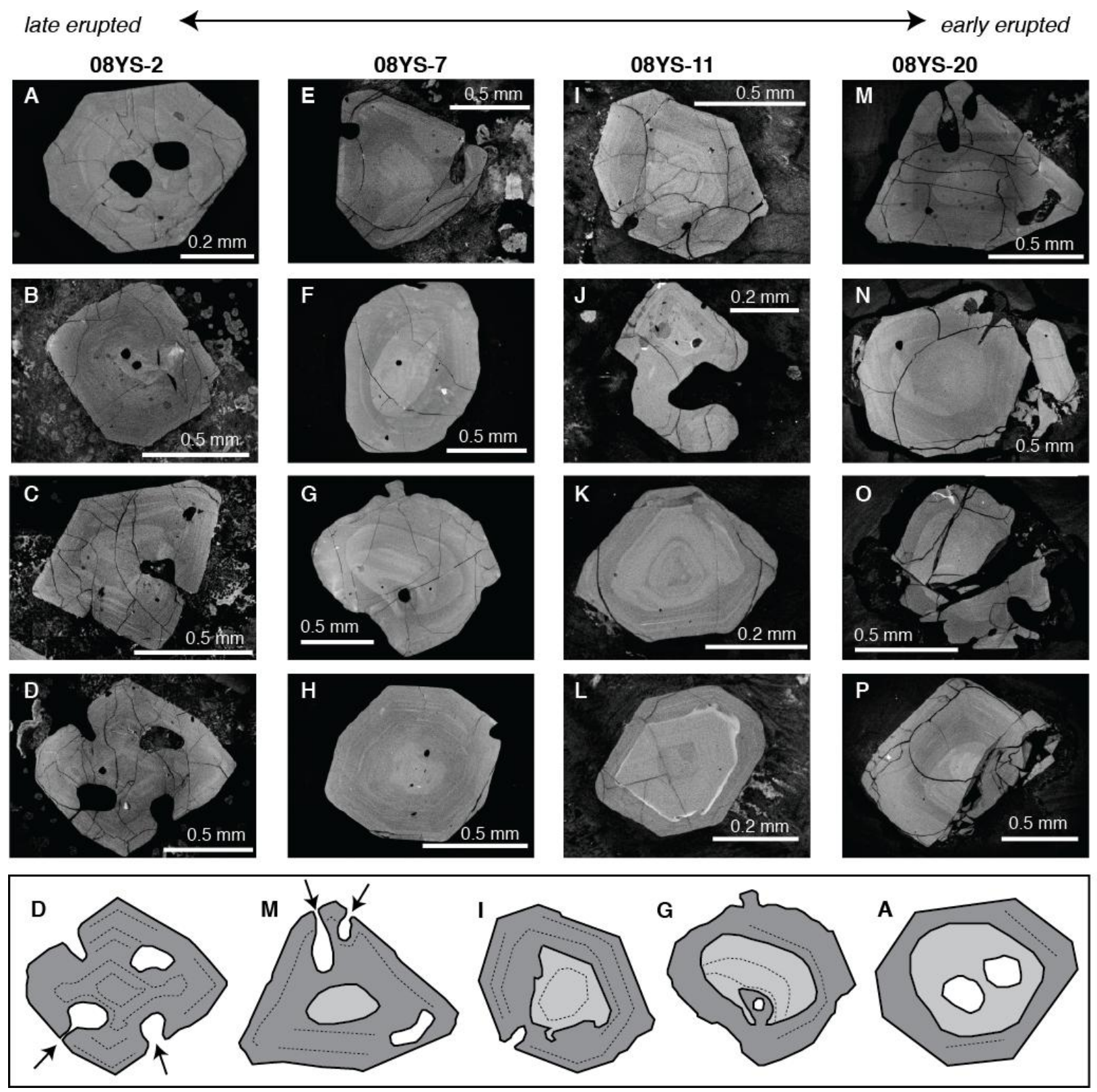

Fig. 5. CL-images of quartz phenocrysts in thin sections from samples collected across the Summit Lake flow. No significant changes in phenocryst morphology or zoning are indicated in early to late erupted samples, except for more common occurrence of broken crystals in the earliest erupted sample (08YS-20). Bright-CL cores are common ( $>50 \%$ of examined phenocrysts), along with hexagonal faceted external morphology, and embayments. Some embayments have extremely narrow necks (C, D, E, M, see arrows in sketches) that can be formed by annealing of rapid, skeletal growth features, and are difficult to imagine forming from dissolution processes. Crystal D resembles a classic skeletal growth pattern, with internal CLzoning reflecting rapid growth at crystal corners followed by annealing and trapping of melt inclusions within embayments. Only three crystals are clearly anhedral in form (F, B, O) and these may result from the angle of crystal sectioning. Interpreted sketches of selected phenocrysts are shown at the bottom, with bright-CL cores in light grey, rims in dark-grey, and surrounding melt, melt embayments, and melt inclusions in white. 
A. 08 YS-2
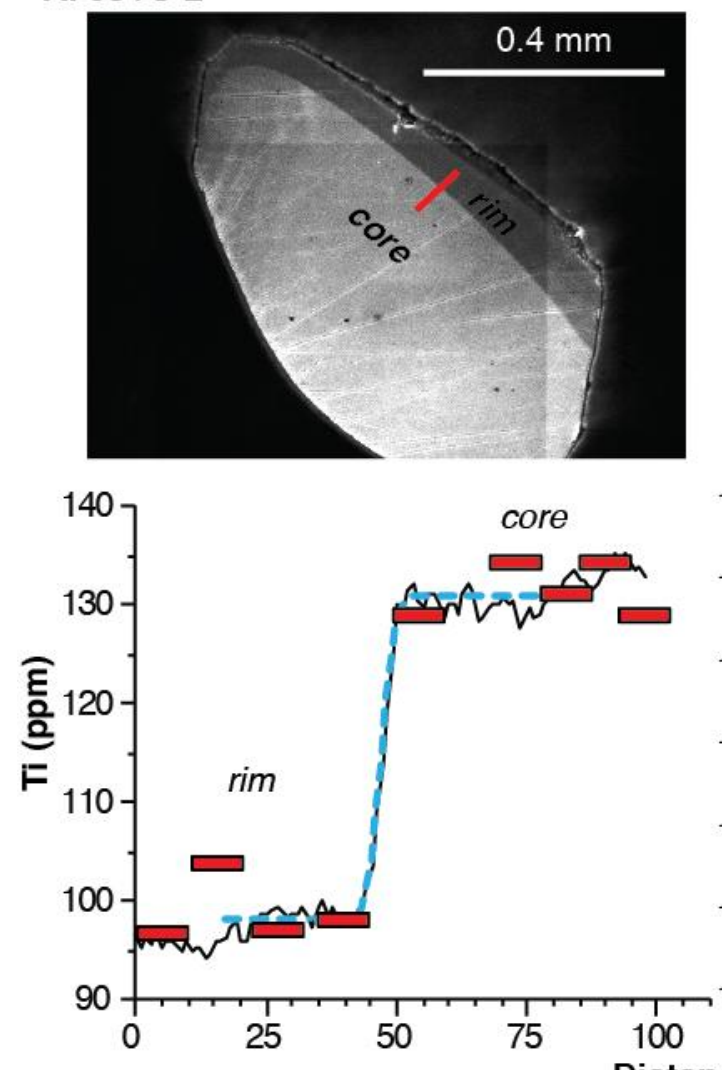

B. $08 Y S-20$
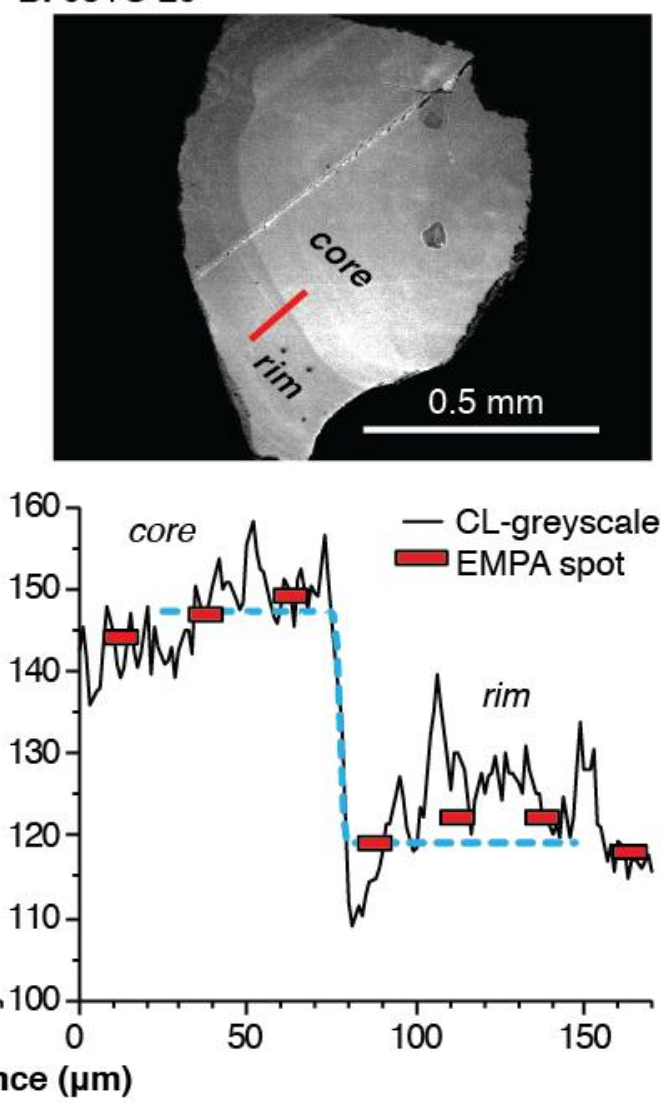

Fig. 6. Strong zoning present in Summit Lake quartz crystals is characterized by a sharp transition between high-Ti cores and low-Ti rims in both late (A) and early (B) erupted samples. Calibrating Cathode Luminescence (CL) greyscale to electron microprobe determinations (following Wark et al., 2007) resolve a $<7 \mu \mathrm{m}$ boundary between core and rim. Blue dashed curve is best-fit diffusion model following the approach of Gualda et al. (2012). Using temperature dependent diffusion coefficients (Cherniak et al., 2007), this line represents a diffusive duration of 96, 21, and 5 years for (A) and 15, 3, and 1 year for (B) at 750, 800, and $850^{\circ} \mathrm{C}$, respectively. 


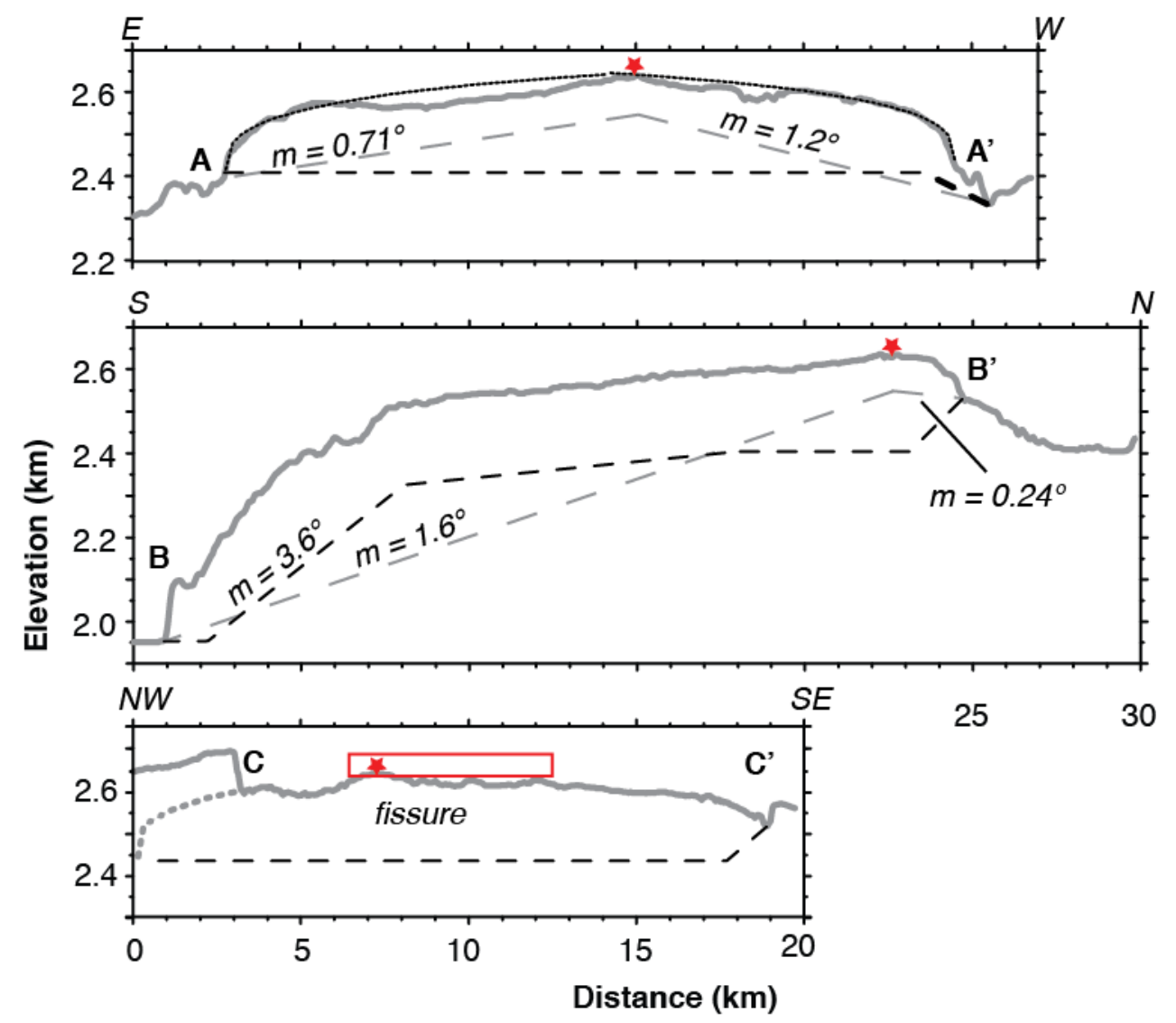

Fig. 7. Cross-sections from Fig. 1. Surface topography is shown in grey. The maximum potential average slopes $(\mathrm{m})$ are shown in grey dashed lines. The dashed black line shows a more likely inferred topography below the Summit Lake Flow that can explain external flow morphology. The black dotted line is a shape predicted by a model of viscous flow over a horizontal surface, from eqn. 1. Final vent location is shown with a star, and the length of our proposed fissure-style vent is shown with a rectangle along $\mathrm{C}-\mathrm{C}$ '. 
A.

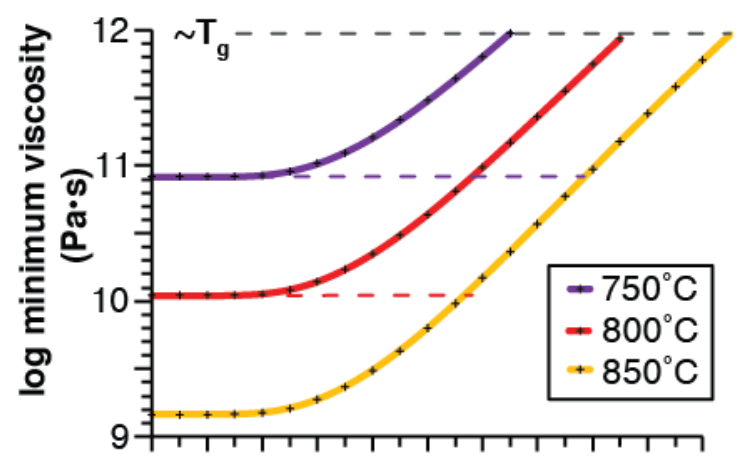

B.

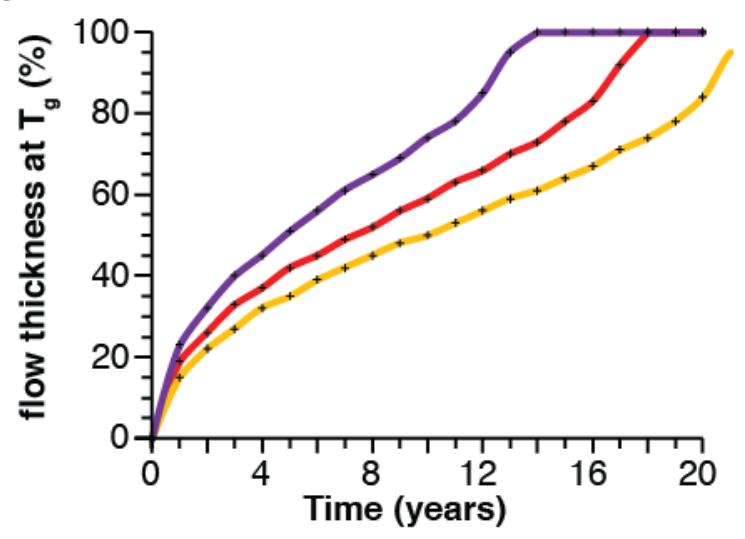

Fig. 8. Conductive cooling model for a $100 \mathrm{~m}$ thick lava flow margin (see Fig. 6) following the approach Farquharson et al. (2015). Solidification of the flow margin will control flow morphology and the occurrence of lava breakouts which are not observed for Summit Lake (see Fig. 1). (A) Compares the minimum viscosity over time. A conductive cooling front will reach the center of a $100 \mathrm{~m}$ thick section after about 5 years for any initial temperature, resulting in sharp increases in viscosity. (B) The proportion of flow below the glass transition temperature $\left(\mathrm{T}_{\mathrm{g}}\right.$ ) increases through time, reaching $100 \%$ by $\sim 13$ years for a $750^{\circ} \mathrm{C}$ initial temperature, 18 years for $800^{\circ} \mathrm{C}$, and 22 years for $850^{\circ} \mathrm{C}$. 


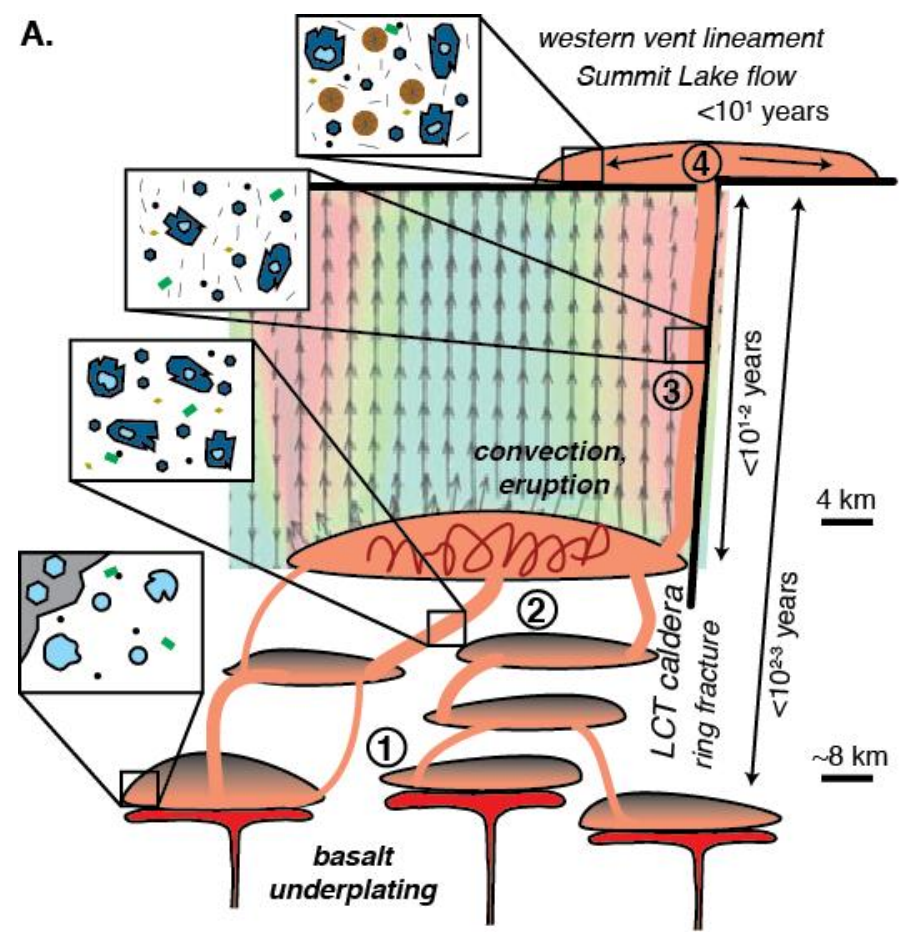

B. Summit Lake, Pitchstone Plateau Bluff Point, Cold Mountain Creek

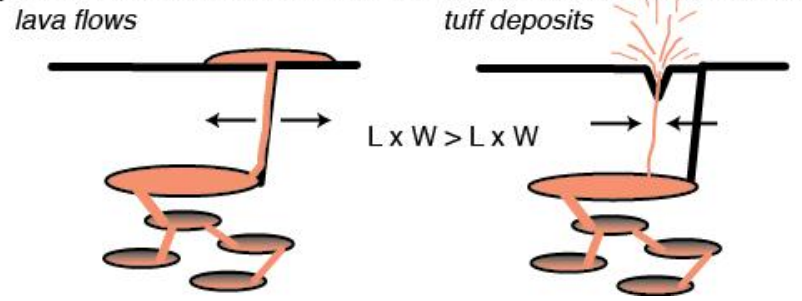

Fig. 9. (A) Synthesis diagram of the eruption of large volume rhyolite lavas. 1. Remelting and merger of hot near-solidus intracaldera rhyolitic batches; high-Ti cores of quartz crystals are inherited from crystalline remnants of earlier CPM magmatic episodes or remobilized from a near-solidus crystal mush. Pyroxene and magnetite crystallize here at near-liquidus temperatures $>900^{\circ} \mathrm{C}$, and preservation of magnetite oxygen isotope compositions constrains the melting event to occur $<\sim 10^{3}$ years from eruption (Loewen and Bindeman, 2016). 2. A pre-eruptive, perhaps ephemeral, magma body is formed at shallow depths from amalgamation of generated melts via dikes and sills and results in lower $<850^{\circ} \mathrm{C}$ temperatures and saturation of accessory minerals zircon and chevkinite, consistent with lower temperature zircon crystallization and geochemical trends observed within individual CPM units. Quartz carried within recharge magmas are undercooled resulting in hopper-style rim growth at the same composition/temperature as low-Ti phenocrysts. The sharpest observed core-rim boundaries constrain the final shallow amalgamation of magmas to within years to decades of eruption and quenching. 3. Eruption proceeds due to overpressure upon melt refill and batch merger (stages 1-2), and volatile exsolution is only achieved during ascent within conduit and triggers microlite crystallization. Eruption proceeds along elongate fissures tracking the LCT caldera boundary (Fig. 1) and likely at the edge of the magma body as is predicted from stress fields in overpressured magma bodies modeled by Bindeman and Simakin (2014; indicated by colors and arrows in the top part of diagram). 4. Gravity-driven flow at $\sim 800^{\circ} \mathrm{C}$ will occur in 2-5 years. Spherulite growth occurs during subsequent subsolidus cooling (Befus et al., 2015a). (B) The origin of effusive vs 
explosive rhyolite eruptions of Yellowstone in response to episodes of high recharge and merger rates. Voluminous lavas: high discharge rate $(\mathrm{Q})$ along zones of preexisting crustal weakness, such as along the caldera ring fractures, results from low ascent velocity through large crosssection dikes (LxW). Tuff eruptions: ascent is via more constricted conduits (smaller $\mathrm{LxW}$ ) and leads to higher ascent rate at equal discharge $\mathrm{Q}$, leading to magma vesiculation and fragmentation during ascent. Diagram is not to scale. 